\title{
Human mesenchymal stromal cells response to biomimetic octacalcium phosphate containing strontium
}

Citation for published version (APA):

Birgani, Z. T., Malhotra, A., van Blitterswijk, C. A., \& Habibovic, P. (2016). Human mesenchymal stromal cells response to biomimetic octacalcium phosphate containing strontium. Journal of Biomedical Materials Research Part A, 104(8), 1946-1960. https://doi.org/10.1002/jbm.a.35725

Document status and date:

Published: 01/08/2016

DOI:

10.1002/jbm.a.35725

Document Version:

Publisher's PDF, also known as Version of record

Document license:

Taverne

Please check the document version of this publication:

- A submitted manuscript is the version of the article upon submission and before peer-review. There can be important differences between the submitted version and the official published version of record.

People interested in the research are advised to contact the author for the final version of the publication, or visit the DOI to the publisher's website.

- The final author version and the galley proof are versions of the publication after peer review.

- The final published version features the final layout of the paper including the volume, issue and page numbers.

Link to publication

\footnotetext{
General rights rights.

- You may freely distribute the URL identifying the publication in the public portal. please follow below link for the End User Agreement:

www.umlib.nl/taverne-license

Take down policy

If you believe that this document breaches copyright please contact us at:

repository@maastrichtuniversity.nl

providing details and we will investigate your claim.
}

Copyright and moral rights for the publications made accessible in the public portal are retained by the authors and/or other copyright owners and it is a condition of accessing publications that users recognise and abide by the legal requirements associated with these

- Users may download and print one copy of any publication from the public portal for the purpose of private study or research.

- You may not further distribute the material or use it for any profit-making activity or commercial gain

If the publication is distributed under the terms of Article $25 \mathrm{fa}$ of the Dutch Copyright Act, indicated by the "Taverne" license above, 


\section{Always Be Ready for What's Next with Patient Safety Net"}

Multiple studies over 10 years at Dartmouth-Hitchcock Medical Center have shown improved clinical outcomes and reduced cost of care.

\section{0}

preventable deaths or brain damage due to opioid-induced respiratory depression in monitored patients over 10 years

\section{$\downarrow 50 \%$}

approximate reduction in ICU transfers ${ }^{2}$

\section{$\downarrow 60 \%$}

approximate reduction in rapid response team activations

\section{$\downarrow 7$ Million}

Masimo SET is used to monitor over 200 million patients a year."

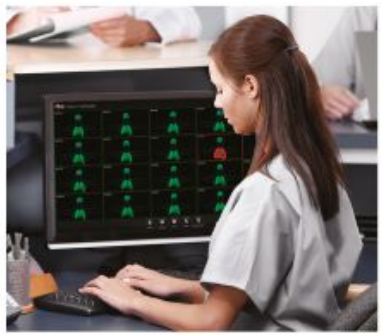

$>$ Masimo $\mathrm{SET}^{s}$ has been shown in more than 100 independent and objective studies to outperform other pulse oximetry technologies ${ }^{5}$

$>$ Radius PPG ${ }^{\text {Th }}$ tetherless pulse oximetry allows you to monitor patients from outside the room and beyond

$>$ Remote patient monitoring at central view stations

$>$ Real-time data and alarm notifications on clinicians' smartphones with Replica ${ }^{\mathrm{T}}$ 


\title{
Human mesenchymal stromal cells response to biomimetic octacalcium phosphate containing strontium
}

\author{
Zeinab Tahmasebi Birgani, ${ }^{1}$ Angad Malhotra, ${ }^{1,2}$ Clemens A. van Blitterswijk, ${ }^{1,2}$ \\ Pamela Habibovic ${ }^{1,2}$ \\ ${ }^{1}$ Department of Tissue Regeneration, MIRA Institute for Biomedical Technology and Technical Medicine, \\ University of Twente, P.O. Box 217, Enschede, 7500 AE, The Netherlands \\ ${ }^{2}$ MERLN Institute for Technology-Inspired Regenerative Medicine, Maastricht University, P.O. Box 616, Maastricht, \\ 6200 MD, The Netherlands
}

Received 9 October 2015; revised 15 March 2016; accepted 21 March 2016

Published online 9 April 2016 in Wiley Online Library (wileyonlinelibrary.com). DOI: 10.1002/jbm.a.35725

Abstract: The incorporation of bioinorganics into synthetic biomaterials is a promising approach to improve the biological performance of bone graft substitutes, while still retaining their synthetic nature. Among these bioinorganics, strontium ions $\left(\mathrm{Sr}^{2+}\right)$ have reported enhanced bone formation, and a reduced risk of bone fractures. While previous results have been encouraging, more detailed studies are needed to further develop specific applications. This study demonstrates the effects of $\mathrm{Sr}^{2+}$ on the osteogenic differentiation of human mesenchymal stromal cells (hMSCs) when introduced as either a dissolved salt, or incorporated into biomimetic calcium phosphate (CaP) coatings. Upon attachment, hMSCs seeded in the presence of higher $\mathrm{Sr}^{2+}$ concentrations presented with a more elongated shape as compared to the controls without $\mathrm{Sr}^{2+}$. Both $\mathrm{Sr}^{2+}$ as a dissolved salt in the medium, or incorporated into CaP coatings, positively influenced hMSC alkaline phosphatase (ALP) activity in a dosedependent manner. At the mRNA level, the expression of osteogenic markers ALP, bone sialoprotein, bone morphogenetic protein 2, osteopontin, and osteoclacin were increased in the presence of $\mathrm{Sr}^{2+}$, independent of the delivery method. Overall, this study demonstrates the positive effects of strontium on the osteogenic differentiation of human MSCs, and supports the use of strontium-incorporated CaPs for bone regeneration applications. $\odot 2016$ Wiley Periodicals, Inc. J Biomed Mater Res Part A: 104A: 1946-1960, 2016.

Key Words: bioinorganics, strontium, calcium phosphate coatings, osteogenic differentiation, human mesenchymal stromal cells

How to cite this article: Tahmasebi Birgani Z, Malhotra A, van Blitterswijk CA, Habibovic P. 2016. Human mesenchymal stromal cells response to biomimetic octacalcium phosphate containing strontium. J Biomed Mater Res Part A 2016:104A:1946-1960.

\section{INTRODUCTION}

Despite advances in orthopedic and dental surgery, the clinical management of bone defects continues to present challenges. ${ }^{1}$ While autograft remains the gold standard for treating bone defects, issues such as limited quantity, donor site morbidity, and the requirement for an additional surgical site continue to encourage research into alternatives. ${ }^{2}$ Synthetic bone graft substitutes have provided promising results to date, with calcium phosphates (CaPs) maintaining interest ${ }^{2}$ due to their chemical similarities to the mineral phase of bone, being itself a nonstoichiometric carbonated apatite. $^{3}$ Despite this, the performance of synthetic bone grafts remains inferior to autograft. Several attempts have been made to improve the bone healing capacity of $\mathrm{CaPs},{ }^{4}$ including combining them with growth factors, ${ }^{5-7}$ cells ${ }^{5,8,9}$ and inorganic additives. ${ }^{10-12}$ The incorporation of inorganic additives such as magnesium $\left(\mathrm{Mg}^{2+}\right)$, copper $\left(\mathrm{Cu}^{2+}\right)$, strontium $\left(\mathrm{Sr}^{2+}\right)$, and fluoride $\left(\mathrm{F}^{-}\right)$into synthetic bone grafts, is gaining popularity as these additives may directly induce changes in cells, for example via ion channels, potentially functioning as "synthetic growth factors." The potential role of these bioinorganics in bone tissue, and their effects on bone formation, are comprehensively summarized by Habibovic and Barralet, ${ }^{13}$ Yang et al., ${ }^{4}$ and Boanini et al. ${ }^{10}$

While many elements have been shown to influence bone regeneration, the role of strontium is particularly interesting due to its relatively high presence within healthy bone. Approximately $98 \%$ of the strontium within the body is found within bone, with its quantity being positively correlated to the compressive strength of bone. ${ }^{13}$ Strontium ranelate is currently used for treatment and management of osteoporotic bone, ${ }^{14-17}$ with its use reported to reduce the

Additional Supporting Information may be found in the online version of this article.

Correspondence to: P. Habibovic; e-mail: p.habibovic@maastrichtuniversity.n

Contract grant sponsor: Dutch Ministry of Economic Affairs, Agriculture and Innovation

Contract grant sponsor: The Netherlands Science Organization (NWO); contract grant number: 015.008.039 
risk of fracture in postmenopausal osteoporotic bone, ${ }^{14}$ and increase bone mineral density. ${ }^{15}$

To date, several studies have investigated the effects of local $\mathrm{Sr}^{2+}$ delivery on osteogenesis and bone formation. Promising results have been obtained when strontium was incorporated into synthetic bone grafts, including bioactive glasses, ${ }^{18-20}$ titanium implants, ${ }^{21,22}$ calcium silicates, ${ }^{23}$ and CaPs. ${ }^{1,11,24-30}$ In vitro studies have previously demonstrated that strontium incorporation into CaPs resulted in a dosedependent effect on osteoblast and osteoclast growth and activity. ${ }^{11,24-27}$ This effect has also been demonstrated using ovariectomized rats, where the ion release from $\mathrm{Sr}^{2+}$-doped CaPs resulted in increased new bone formation ${ }^{28}$ and improved osseointegration. ${ }^{29}$

While the addition of strontium ions to $\mathrm{CaP}$ bone graft substitutes has provided positive results to date, a deeper understanding of the mechanisms and function of strontium is still lacking. Such information is needed to convert this potential into applicable products. To further elucidate the specific role of strontium in bone healing, this study investigated the effect of $\mathrm{Sr}^{2+}$ on hMSCs in two conditions. In the first condition, $\mathrm{Sr}^{2+}$ ions were delivered to the cells as a dissolved salt, in order to understand its direct effect on hMSCs. In comparison, and with the aim to assess a degradable $\mathrm{CaP}$ as a delivery vehicle for this ion, the second condition used a two-step biomimetic approach to incorporate $\mathrm{Sr}^{2+}$ at varying concentrations into crystalline CaP coatings, which were deposited on titanium substrate. For both conditions, cell responses were studied using proliferation and osteogenic differentiation marker expression, and changes in hMSC morphology. Overall, this study was undertaken to elucidate the specific mechanisms of strontium-induced osteogenesis, and therefore, improve the efficacy of CaPs as bone graft substitutes

\section{MATERIALS AND METHODS}

\section{Coating preparation}

Commercially pure Titanium (cp Ti grade 4) was used as a substrate for the CaP coatings. The Ti sheet was cut into $1 \times 1 \mathrm{~cm}^{2}$ pieces and grit-blasted using alumina beads with a diameter of $250 \mu \mathrm{m}$ to reach a Ra roughness of $1.3 \pm 0.1 \mu \mathrm{m}$.

A 2-step biomimetic coating approach was used to prepare the coatings, as previously described. ${ }^{11,31}$ Briefly, the surface of the Ti plates were coated with a thin amorphous $\mathrm{CaP}$ layer by vertical immersion in a supersaturated simulated body fluid (SBF) for $24 \mathrm{~h}$ at $37^{\circ} \mathrm{C}$. This solution, containing $\mathrm{NaCl}, \mathrm{CaCl}_{2} \cdot 2 \mathrm{H}_{2} \mathrm{O}, \mathrm{MgCl}_{2} \cdot 6 \mathrm{H}_{2} \mathrm{O}, \mathrm{NaHCO}_{3}$, and $\mathrm{Na}_{2} \mathrm{HPO}_{4} \cdot 2 \mathrm{H}_{2} \mathrm{O}$ salts (Sigma, Table I) was prepared under mildly acidic conditions by dissolution of $\mathrm{CO}_{2}$ gas. The precalcified Ti plates were then immersed for $48 \mathrm{~h}$ at $37^{\circ} \mathrm{C}$ in a calcium phosphate solution (CPS) containing $\mathrm{NaCl}$, $\mathrm{CaCl}_{2} .2 \mathrm{H}_{2} \mathrm{O}$, and $\mathrm{Na}_{2} \mathrm{HPO}_{4} .2 \mathrm{H} 2 \mathrm{O}$ salts (Sigma, Table I) that was buffered at $\mathrm{pH} 7.4$ by addition of trishydrozymethylaminomethane (Tris) and $1 M$ HCL (Sigma). A stock solution of strontium acetate (Sigma) in a Tris buffer $(\mathrm{pH}=7.4)$ with concentration of $100 \mathrm{mM}$ was prepared. To incorporate strontium into $\mathrm{CaP}$ coatings, appropriate vol-
TABLE I. Ionic Content of Concentrated SBF and CPS Solutions used for Preparation of the Coatings

\begin{tabular}{lcccccc}
\hline Solution & $\mathrm{Na}^{+}$ & $\mathrm{Mg}^{2+}$ & $\mathrm{Ca}^{2+}$ & $\mathrm{Cl}^{-}$ & $\mathrm{HPO}_{4}^{2-}$ & $\mathrm{HCo}^{3-}$ \\
\hline $\begin{array}{l}\text { Concentrated } \\
\text { SBF }\end{array}$ & 733.5 & 7.5 & 12.5 & 720 & 5 & 21 \\
CPS & 140 & 0 & 4 & 144 & 2 & 0 \\
\hline
\end{tabular}

umes of $\mathrm{Sr}^{2+}$ stock solution were combined with the CPS solution to reach varying concentrations of $\mathrm{Sr}^{2+}$ in CPS $(0$, 10 , and $1000 \mu M$ ). The CPS solution was refreshed after $24 \mathrm{~h}$. The coatings were then washed three times with MilliQ water and dried overnight at $37^{\circ} \mathrm{C}$ in an air oven.

\section{Coating characterization}

The chemistry of the mineral phase was characterized by Fourier transform infrared spectroscopy (FTIR, PerkinElmer Spectrum 1000) and X-ray diffraction (XRD, Miniflex, Rigaku). The morphology of the mineral films, and the presence and distribution of calcium, phosphorus, and strontium were investigated scanning electron microscopy (SEM, XL30 ESEM-FEG, Philips), coupled with energy dispersive Xray spectroscopy analyzer (EDS, EDAX, AMETEK Materials Analysis Division). Quantification of the data was achieved using the TEAM ${ }^{\mathrm{TM}}$ EDS V2.2 software provided by the EDS manufacturer. The $\mathrm{Ca} / \mathrm{P}, \mathrm{Sr} / \mathrm{P},(\mathrm{Ca}+\mathrm{Sr}) / \mathrm{P}$, and $\mathrm{Sr} / \mathrm{Ca}$ ratios were calculated upon analysis.

Additionally, the coatings were dissolved in ultrapure nitric acid and the $\mathrm{Sr}^{2+}$ content of the coating was measured using inductively coupled plasma mass spectrometry (ICP-MS, Agilent 7700 ICP-MS, Agilent Technologies).

\section{Cell subculture}

hMSCs were isolated from bone marrow aspirates (5$20 \mathrm{~mL}$ ) obtained from 2 donors after written informed consent. Isolation procedure and full characterization of the cells have been described previously. ${ }^{32,33}$ In short, aspirates were resuspended using $20 \mathrm{G}$ needles, plated at a density of $5 \times 10^{5}$ cells per $\mathrm{cm}^{2}$, and cultured in proliferation medium [consisting of $\alpha$-MEM (Gibco) supplemented with 10\% fetal bovine serum (Lonza), $2 \mathrm{~m} M$ L-glutamine (Gibco), $0.2 \mathrm{mM}$ ascorbic acid (Sigma), $100 \mathrm{U} \mathrm{mL}^{-1}$ penicillin and 100 $\mu \mathrm{g} \mathrm{mL}^{-1}$ streptomycin (Gibco), and $1 \mathrm{ng} \mathrm{ml}^{-1}$ rhbFGF (AbDSerotec)]. The medium was refreshed every 2-3 days. Cells were harvested at $\sim 80 \%$ confluency for subculture until they reached passage 3 .

\section{Cell culture}

In the first step of cell culture, hMSCs of passage 3 from the 2 donors were seeded on treated tissue culture plates (TCPs) at a density of 10,000 cells $/ \mathrm{cm}^{2}$ [for DNA, alkaline phosphatase (ALP), and qPCR assays] or at 2500 cells $/ \mathrm{cm}^{2}$ (for imaging cell morphology) in $\sim 50 \mu \mathrm{L}$ of basic medium [ $\alpha$-MEM (Gibco) supplemented with 10\% fetal bovine serum (Lonza), $2 \mathrm{mM}$ L-glutamine (Gibco), $0.2 \mathrm{mM}$ ascorbic acid (Sigma), $100 \mathrm{U} \mathrm{ml}^{-1}$ penicillin and $100 \mu \mathrm{g} \mathrm{ml}^{-1}$ streptomycin (Gibco)]. After seeding, $1 \mathrm{~mL}$ of either basic or osteogenic medium [basic medium supplemented with $10 \mathrm{nM}$ 
dexamethasone (Sigma)] was added to each well. Appropriate volumes of $\mathrm{Sr}^{2+}$ stock was added to each well to reach $\mathrm{Sr}^{2+}$ concentrations of 0,10 , and $1000 \mu \mathrm{M}$ in cell culture medium. The medium was refreshed every 2-3 days.

In parallel, hMSCs of two donors were cultured on coated Ti plates. CaP coatings were sterilized with ethanol prior to cell culture. To sterilize, the samples were placed in a sterile nontreated well plate and washed three times with $70 \%$ ethanol followed by $15 \mathrm{~min}$ of drying inside the flow cabinet after each washing step. In the last step of sterilization, $100 \%$ ethanol was added to the samples and allowed to evaporate in the flow cabinet for at least $2 \mathrm{~h}$. The plates were then washed twice with sterile PBS, followed by an overnight incubation in a $5 \% \mathrm{CO}_{2}$ humid atmosphere at $37^{\circ} \mathrm{C}$ after the addition of $1 \mathrm{~mL}$ basic medium. hMSCs of passage 3 from 2 donors were seeded on the coated $\mathrm{Ti}$ plates at a density of 10,000 cells $/ \mathrm{cm}^{2}$ (for DNA, ALP, and qPCR assays) or 2500 cells $/ \mathrm{cm}^{2}$ (for imaging cell morphology) in $\sim 50 \mu \mathrm{L}$ of basic medium and allowed to attach to the coatings for $4 \mathrm{~h}$, after which $1 \mathrm{~mL}$ of either basic or osteogenic medium was slowly added to each well. The medium was refreshed every 2-3 days. Cell medium was collected at each refreshment point and concentrations of $\mathrm{Ca}$ and $\mathrm{Sr}$ in basic cell medium were then measured using ICP-MS, at each refreshment point up to 7 days.

\section{Cell morphology}

At day 1 after cell seeding, the cells cultured on TCPs and $\mathrm{CaP}$ coatings were washed with PBS and fixed with a buffer of $4 \%$ paraformaldehyde $(\mathrm{pH}=7.4)$ for $30 \mathrm{~min}$. The cells cultured on TCPs and CaP coatings were then permeabilized with $0.1 \%$ Triton X-100 in PBS solution for $10 \mathrm{~min}$, washed with PBS and blocked for $30 \mathrm{~min}$ in a blocking solution (2\% bovine serum albumin and $0.1 \mathrm{v} / \mathrm{v} \%$ Tween 20 in PBS). Subsequently, Alexa Fluor 594 antibody (Invitrogen) diluted in blocking buffer was added to the cells to stain the cell cytoskeleton, and incubated at room temperature in dark for 1 hour. After incubation, cells were washed with PBS, and DAPI antibody (Sigma-Aldrich/Fluka) diluted in PBS was added for $10 \mathrm{~min}$. The cells were then washed with PBS and imaged using a fluorescent microscope (E600, Nikon; the data is not shown for cells cultured on CaP coatings).

Six pairs of immunofluorescent images obtained in blue and red channels (for Dapi and Phalloidin antibodies, respectively) were used for quantifying cell shape parameters. The data was analyzed in CellProfiler software as was described previously ${ }^{34}$ and cell area and eccentricity parameters were selected to assess the changes in cell morphology upon introduction of $\mathrm{Sr}^{2+}$. Cell area shows the total number of pixels located in the cell area. Eccentricity shows morphological elongation and measures the deviation of a conic section from a circle, with eccentricity being equal to zero for a circle and one for a parabola. ${ }^{35}$

After fixation, the cells cultured on CaP coatings were also dehydrated by addition of alcohol series (70, 80, 90, and $100 \%, 30$ min per concentration) and dried using a critical point drier (CPD 030, Balzers). The samples were then gold sputtered and imaged using SEM. Two independent experiments with $n=2$ for each condition were performed.

\section{DNA content and ALP activity quantification}

Total DNA was assessed with CyQuant Cell Proliferation Assay kit (Invitrogen). After 3 freeze/thaw cycles at $-80^{\circ} \mathrm{C}$, $500 \mu \mathrm{L}$ lysis buffer (lysis buffer provided in the kit diluted in a buffer of NaCl-EDTA solution) was added to each well. The samples were ultra-sonicated and incubated at room temperature for $1 \mathrm{~h}$. After centrifugation, $100 \mu \mathrm{L}$ of the supernatant was mixed with the same volume of CyQuant GR dye in a 96 well microplate and incubated for $15 \mathrm{~min}$. Fluorescence measurements for DNA quantification were done at excitation and emission wavelengths of 480 and $520 \mathrm{~nm}$, respectively, using a spectrophotometer (Perkin Elmer). ALP activity in the cultures was measured using a CDP-star kit (Roche Applied Science); $10 \mu \mathrm{L}$ of the supernatant was mixed with $40 \mu \mathrm{L}$ CDP-star reagent in a 96 well microplate and incubated for $30 \mathrm{~min}$. After incubation, chemiluminescence measurements were completed at $466 \mathrm{~nm}$. Results of the DNA assays are presented based on average $\mu \mathrm{g}$ of DNA detected in each condition. Results of ALP activity were normalized per DNA content of each culture and presented as the average of normalized ALP activity per $\mu \mathrm{g}$ of DNA for each condition. Two independent experiments with $n=3$ for each condition were performed for DNA and ALP analyses, and the results of one representative experiment are presented here.

\section{RNA extraction and gene expression (qPCR) assay}

Total RNA was isolated by using a NucleoSpin® RNA II isolation kit (Macherey Nagel) for cells cultured on TCPs and in combination with NucleoSpin ${ }^{\circledR}$ RNA II isolation kit and Trizol method, in accordance with the manufacturer's protocol. RNA was collected in RNAse-free water and the total concentration was measured using nano-drop measurement equipment (ND1000 spectrophotomer, Thermo Scientific). The cDNA of the cultures were then prepared using an iScript kit (Bio-Rad) according to the manufacturer's protocol and diluted 10 times in RNAse-free water to be used for quantitative real-time PCR (qPCR). The qPCR measurements were completed using Bio-Rad equipment using Syber green I master mix (Invitrogen) and the primer sequences (Sigma), which are listed in Table II. Expression of the osteogenic marker genes were normalized to GAPDH levels and fold inductions were calculated by using $\Delta \Delta \mathrm{CT}$ method. hMSCs cultured on TCPs in basic medium for 7 days were used as calibrator. Two independent experiments with $n=3$ for each condition were performed for the qPCR analysis, and the results of one representative experiment are presented here.

\section{Statistical analysis}

Statistical comparisons were performed using One-way Analysis of Variance (ANOVA) followed by a Tukey's multiple comparison post-hoc test. Error bars indicate one 
TABLE II. Primer Sequence of the Osteogenic Genes Investigated

\begin{tabular}{ll}
\hline Gene & \multicolumn{1}{c}{ Primer Sequences } \\
\hline GAPDH (housekeeping & 5'-CCATGGTGTCTGAGCGATGT \\
gene) & 5'-CGCTCTCTGCTCCTCCTGTT \\
Alkaline phosphatase & 5'-TTCAGCTCGTACTGCATGTC \\
(ALP) & 5'-ACAAGCACTCCCACTTCATC \\
Bone morphogenetic & 5'-GCATCTGTTCTCGGAAAACCT \\
protein 2 (BMP2) & 5'-ACTACCAGAAACGAGTGGGAA \\
Bone sialoprotein (BSP) & 5'-TCCCGTTCTCACTTTCATA \\
& 5'-CCCCACCTTTTGGGAAAAC \\
Osteocalcin (OC) & 5'-CGCCTGGGTCTCTTCACTAC \\
& 5'-TGAGAGCCCTCACACTCCTC \\
Osteopontin (OP) & 5'-CCAAGTAAGTCCAACGAAAG \\
& 5'-GGTGATGTCCTCGTCTGTA \\
\hline
\end{tabular}

standard deviation. For all figures, the following $p$-values apply: ${ }^{*} p<0.05$.

\section{RESULTS}

\section{Mineral film characterization}

The 2-step biomimetic technique employed for preparation of the CaP coatings resulted in the formation of a uniform crystalline CaP layer that covered the entire surface of the Ti plates [Fig. 1(a-c)]. The SEM micrographs showed CaP crystals with a plate-like morphology, which formed perpendicular to the surface of the Ti plates. The morphology of the crystals was modified by addition of $\mathrm{Sr}^{2+}$ to the initial CPS solution. $\mathrm{Sr}^{2+}$-added CPS solution resulted in smaller and less sharp CaP crystals [Fig. 1(c)].

The presence of the CaP film was confirmed by EDS spectra of the samples, in which sharp peaks of calcium, phosphorous, and oxygen were visible [Fig. 1(d-f)]. EDS elemental maps also showed that $\mathrm{Ca}$ and $\mathrm{P}$ elements were homogeneously distributed on the surface [Fig. 1(g-l)]. EDS results showed presence of $\mathrm{Sr}^{2+}$ in the CaP coatings prepared with a concentration of $1000 \mu \mathrm{M} \mathrm{Sr}^{2+}$ in the CPS solution [Fig. 1(f)]. The EDS strontium elemental maps indicated that $\mathrm{Sr}^{2+}$ was homogeneously distributed within the coating [Fig. 1(m-o)]. Quantification of the EDS results indicated an incorporation of approximately 3 at $\%$ of strontium into $\mathrm{CaP}$ coatings at the highest concentration of $\mathrm{Sr}^{2+}$ in CPS solution (Table III). EDS did not detect $\mathrm{Sr}^{2+}$ in the coating with low $\mathrm{Sr}^{2+}$ incorporation. However, ICP measurements showed the presence of 0.44 and $16.49 \mathrm{mg} / \mathrm{l} \mathrm{Sr}^{2+}$ in the coatings with low and high incorporation of $\mathrm{Sr}^{2+}$ dissolved in $\mathrm{HNO}_{3}$, respectively (Table III). Comparing the measurement method averages, the ICP measured $\mathrm{Sr} / \mathrm{Ca}$ at $\%$ ratio as $0.01,0.22$, and 10.32, whereas the EDS measured the $\mathrm{Sr} / \mathrm{Ca}$ at\% ratio as $1.75,1.88$, and 8.89 , for the OCP Sr0, OCP Sr10, and OCP Sr1000, respectively. Calculation of atomic ratios indicated that the ratio of $\mathrm{Sr} / \mathrm{P}$ increased from 0.021 to 0.098 by increasing the concentration of $\mathrm{Sr}^{2+}$ in CPS solution from 0 to $1000 \mu M$. The $\mathrm{Ca} / \mathrm{P}$ ratio in these conditions, however, was calculated to be 1.197 and 1.091, respectively. The $(\mathrm{Ca}+\mathrm{Sr}) / \mathrm{P}$ ratios remained constant at $\sim 1.2$.
The results of the XRD and FTIR analyses for CaP coatings without and with $\mathrm{Sr}^{2+}$ (Fig. 2) were in accordance with data obtained in earlier studies when similar biomimetic coating method was applied. ${ }^{36-38}$ The XRD patterns [Fig. $2(\mathrm{a})]$ of the coatings exhibited peaks at $2 \theta=4.7^{\circ}$ corresponding to (010) diffraction line and at $2 \theta=25.8^{\circ}$ corresponding to (002) plane, both typical of triclinic octacalcium phosphate (OCP) crystals. The peaks observed at $2 \theta=9.8^{\circ}$ and at $2 \theta=27-28.5^{\circ}$ can also be attributed to the OCP structure. The broad set of peaks at $\sim 2 \theta=31.5^{\circ}$ to $32.5^{\circ}$ are common for both OCP and apatitic structures. A small shift of $\sim 2 \theta=0.1^{\circ}$ toward lower degrees was observed in some of the characteristic OCP peaks, when the OCP Sr1000 coating was analyzed. Supporting Information Figure S1 summarizes the position of the main peaks in the XRD patterns of the coatings without and with $\mathrm{Sr}^{2+}$ incorporation.

The FTIR spectra of the coatings [Fig. 2(b)] exhibited sharp P-O bands at 560 and $600 \mathrm{~cm}^{-1}$. Moreover, the bands at 906 and $850 \mathrm{~cm}^{-1}$ were typical $\mathrm{HPO}_{4}^{2-}$ bands in the ОСР phase. Nevertheless the vibration bands observed between 1020 and $1070 \mathrm{~cm}^{-1}$ were less sharp and less numerous as compared to phase-pure OCP. ${ }^{37,38}$ The small bands observed at 1450 and at $1480 \mathrm{~cm}^{-1}$ corresponded to the carbonate group typical of A-B carbonated apatite, suggesting that apart from the OCP, the coating comprised a carbonated apatitic phase. The typical $\mathrm{PO}_{4}^{3-}$ and $\mathrm{HPO}_{4}^{-}$bands of the coatings prepared in presence of higher concentration of $\mathrm{Sr}^{2+}$ were less sharp, suggesting a decrease in crystallinity.

\section{Cell morphology}

Cells cultured on TCPs with $1000 \mu M \mathrm{Sr}^{2+}$ in the basic medium appeared to have a higher aspect ratio compared to cells cultured in basic medium without $\mathrm{Sr}^{2+}$ addition, while no apparent differences were observed between the control, and the cells treated with $10 \mu M$ of $\mathrm{Sr}^{2+}$ [Fig. 3(a-c)].

Quantification of the cell parameters using CellProfiler based on immunofluorescent images showed that the cell area was reduced dose-dependently when $\mathrm{Sr}^{2+}$ was added to cell medium. The eccentricity was, however, significantly increased upon addition of $\mathrm{Sr}^{2+}$ to cell medium in a dosedependent manner, confirming increase in elongation of the cells treated with $\mathrm{Sr}^{2+}$.

Similar results were obtained when cells were cultured on OCP coatings. After 1 day, cells cultured on OCP Sr1000 coatings appeared more elongated in their morphology compared with the cells cultured on OCP and OCP Sr10 coatings [Fig. 4(d-f)]. The adhesion points were observed in the cells cultured on all the coatings [Fig. 3(g-i)].

Quantification of the morphology parameters of the cells cultured on CaP coatings based on immunofluorescent images indicated that area of the cells cultured on OCP Sr10 was significantly higher than the area of those cultured on OCP without strontium incorporation. The eccentricity of cells cultured on OCP Sr1000 was also significantly higher than the one of the cells cultured on OCP and OCP Sr10 coatings. 
OCP
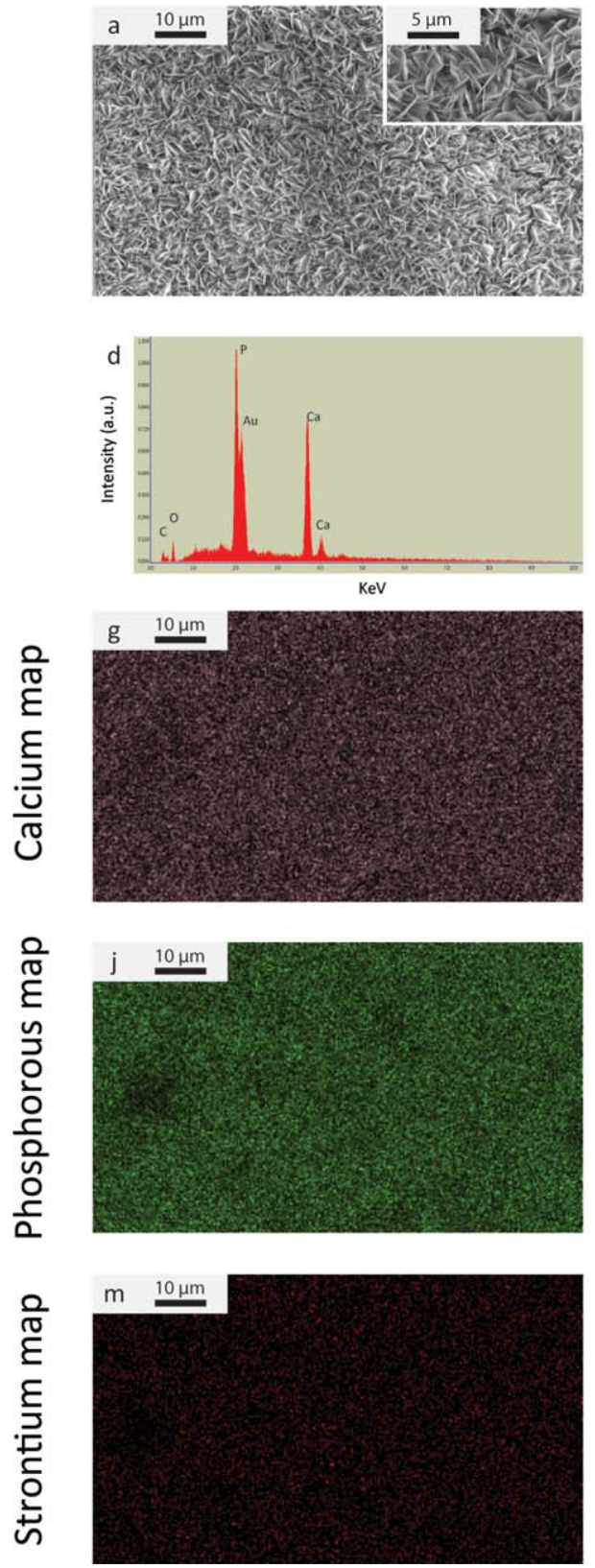

OCP Sr10
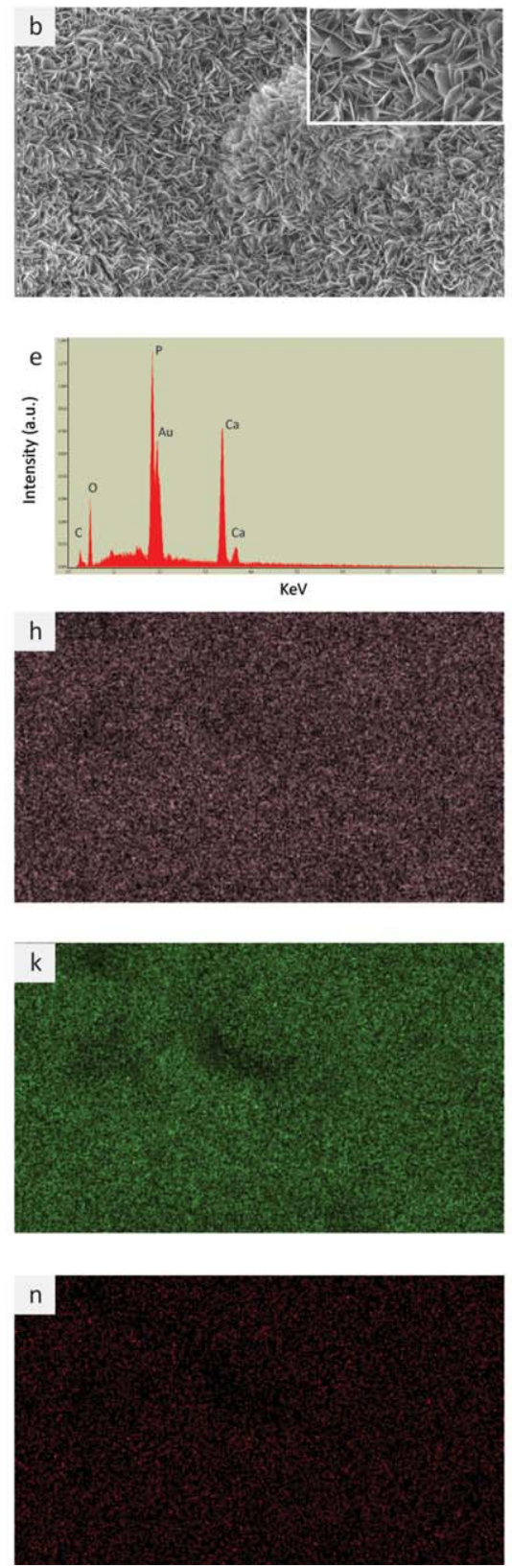

OCP Sr1000
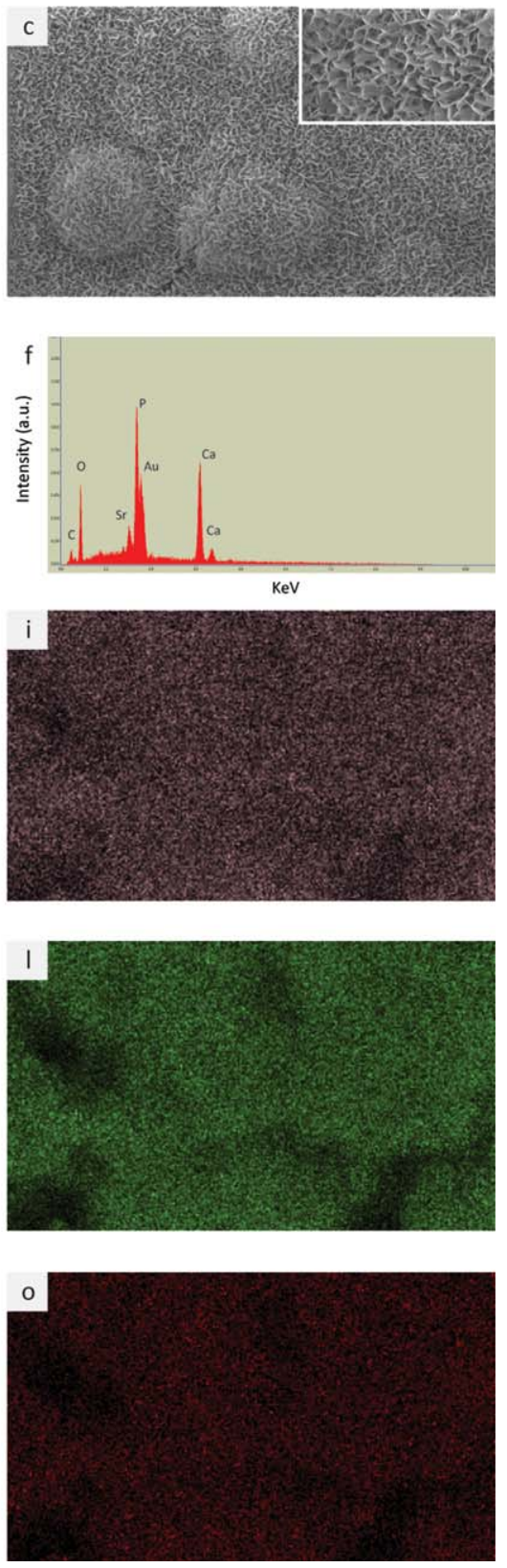

FIGURE 1. SEM images $(a, b, c)$, EDS spectra ( $d, e, f), C a$ elemental map $(g, h, i), P$ elemental map (j,k,l) and Sr elemental map (m,n,o) of OCP, OCP Sr10, and OCP S1000, respectively. A crystalline CaP layer was formed on the surface of Ti plates with a homogenous distribution of all the elements. Presence of $\mathrm{Sr}^{2+}$ in higher concentration was detected in EDS spectrum and Sr elemental map of OCP Sr1000. Moreover, the morphology of the coatings changed upon addition $1000 \mu \mathrm{Sr}^{2+}$ to CPS solution resulting in smaller and less sharp crystals.

\section{DNA content and ALP activity}

At 7 days, the addition of $1000 \mu M \mathrm{Sr}^{2+}$ to the osteogenic media increased the hMSC DNA content in both donors when cultured on TCPs, however, this increase was only significant in cells of Donor 1. A similar trend was seen when $1000 \mu \mathrm{M}$ of $\mathrm{Sr}^{2+}$ was added to basic media in Donor $1 \mathrm{cul}-$ tures, but not when cells from Donor 2 were cultured [Fig. $4(a, b)]$. The DNA content of the cells did not increase between 7 and 14 days, suggesting the formation of a confluent monolayer before the second time point analysis.
While at 7 days, no significant differences in ALP activity were seen among the conditions, at 14 days, the addition of either 10 or $1000 \mu \mathrm{MSr}^{2+}$ to osteogenic media increased the normalized ALP activity of hMSCs. This result was statistically significant for cells of Donor 1 , and for $1000 \mu M$ in Donor 2 cells [Fig. 4(c,d)].

No differences in DNA content were seen when cells were cultured on coatings for 7 days, however, at 14 days in Donor 2 cells, the incorporation of $\mathrm{Sr}^{2+}$ into OCP increased the DNA content, with this result being 
TABLE III. Sr Content Measured by EDS and ICP, and Atomic Ratios Quantified Based on EDS Data in CaP Coatings

\begin{tabular}{lccccc}
\hline Sample & $\begin{array}{c}\text { Sr Content (at\%) } \\
\text { Measured by EDS }\end{array}$ & $\begin{array}{c}\text { Sr Content (mg/L) } \\
\text { Measured by ICP }\end{array}$ & $\begin{array}{c}\text { Ca/P ratio } \\
\text { Measured } \\
\text { by EDS }\end{array}$ & $\begin{array}{c}\text { Sr/P ratio } \\
\text { Measured } \\
\text { by EDS }\end{array}$ & $\begin{array}{c}\text { (Ca }+ \text { Sr)/P ratio } \\
\text { Measured } \\
\text { by EDS }\end{array}$ \\
\hline OCP Sr0 & 0.780 & 0.024 & 1.197 & 0,021 & 1,218 \\
OCP Sr10 & 0,698 & 0.444 & 1,168 & 0,021 & 1,189 \\
OCP Sr1000 & 2.964 & 16.490 & 1.091 & 0,097 & 1,189 \\
\hline
\end{tabular}

The Sr content in OCP Sr1000 was $\sim 3$ at\%, whereas the content of both OCP and OCP Sr10 coating was within the background noise, below 1 at\%. Increasing the concentration of $\mathrm{Sr}^{2+}$ in $\mathrm{CPS}$ solution resulted in increasing in $\mathrm{Sr} / \mathrm{P}$ and a slight decrease in the $\mathrm{Ca} / \mathrm{P}$ ratios, while $(\mathrm{Ca}+\mathrm{Sr}) / \mathrm{P}$ ratio constantly remained at $\sim 1.2$.

statistically significant for both basic and osteogenic media at both incorporation concentrations. This effect, however, was not observed in Donor 1 cells. A difference in proliferation profile was observed between the cells from the two donors, with an increase in DNA content between day 7 and day 14 for the cells from Donor 2 but not for the Donor 1 cells [Fig. 5(a,b)].

At 14 days, the incorporation of $\mathrm{Sr}^{2+}$ into OCP at the higher concentration (OCP Sr1000) increased the ALP activity in Donor 1 , with this result being statistically significant in both basic and osteogenic media. This effect was also observed in osteogenic medium in Donor 2 cells [Fig. $5(\mathrm{c}, \mathrm{d})]$.

\section{Expression of osteogenic markers at mRNA level}

While in basic medium, no significant differences in ALP mRNA expression of cells cultured on TCPs were observed among the conditions at either time point, at 7 days, the addition of $1000 \mu \mathrm{M}$ of $\mathrm{Sr}^{2+}$ to the osteogenic media significantly increased the ALP expression in Donor 1 cells. At 14

a

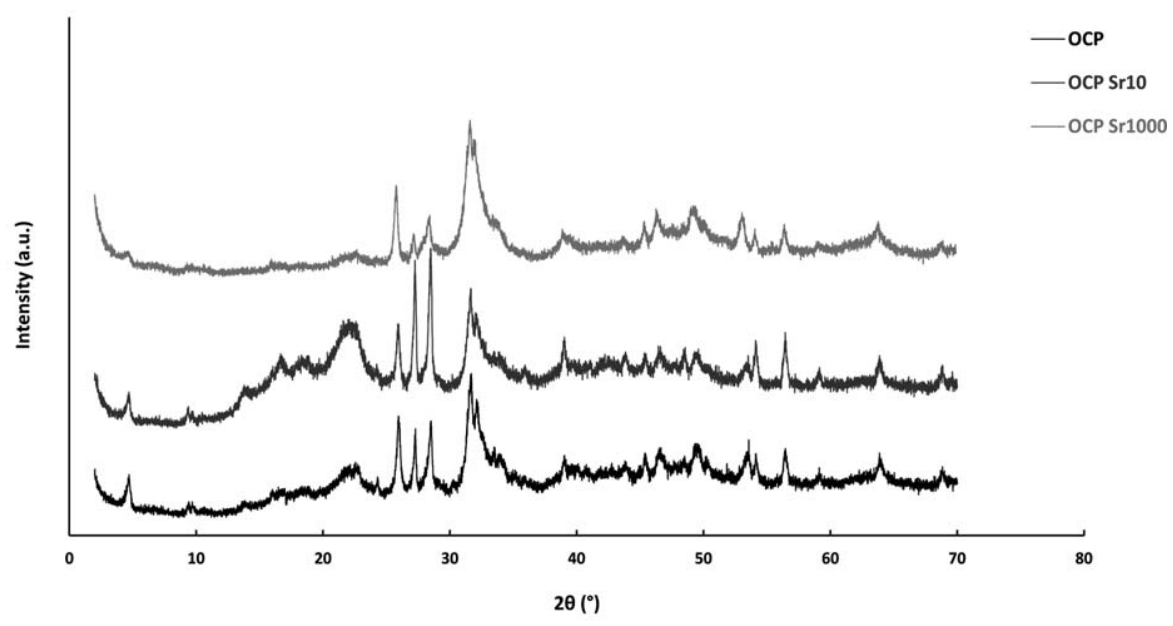

b

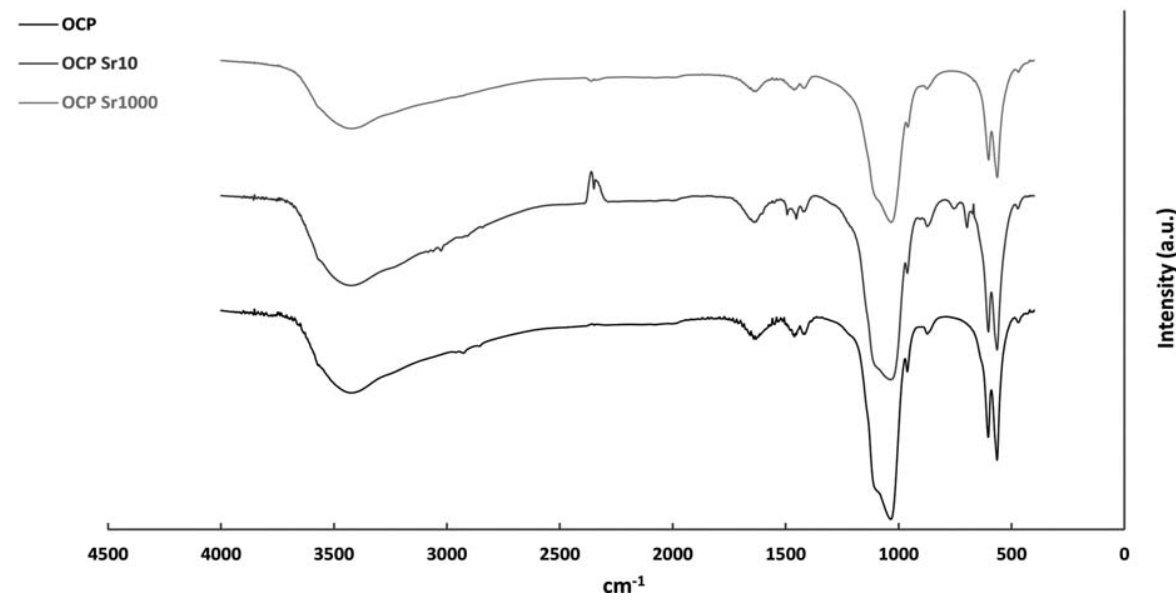

FIGURE 2. XRD patterns (a) and FTIR Spectra (b) of the coatings. The XRD patterns and the FTIR spectra suggested that the coatings predeminantly consisted of OCP, with presence of some carbonated apatite. Furthermore, the data suggested that an increase of $\mathrm{Sr}^{2+}$ content of the coating led to a limited decrease in crystallinity. 


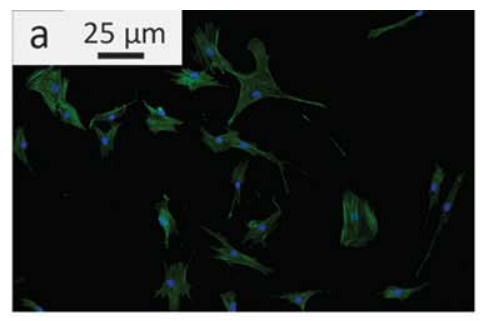

d

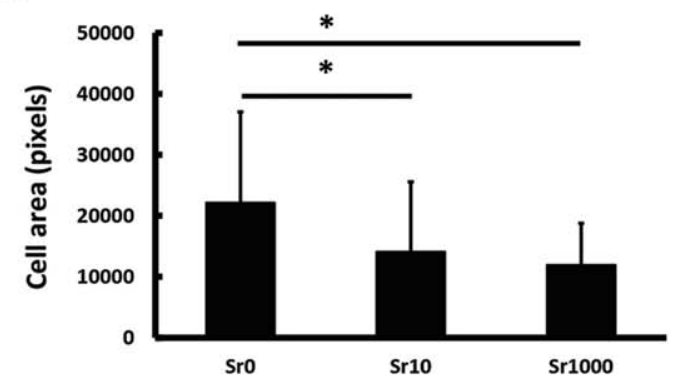

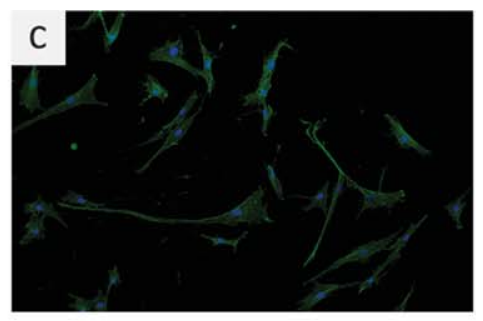

e

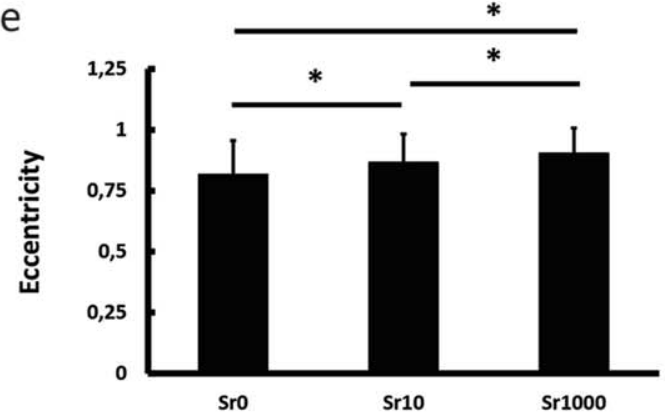

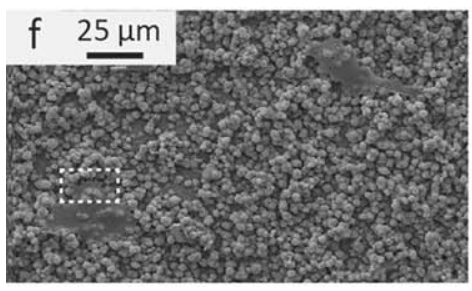
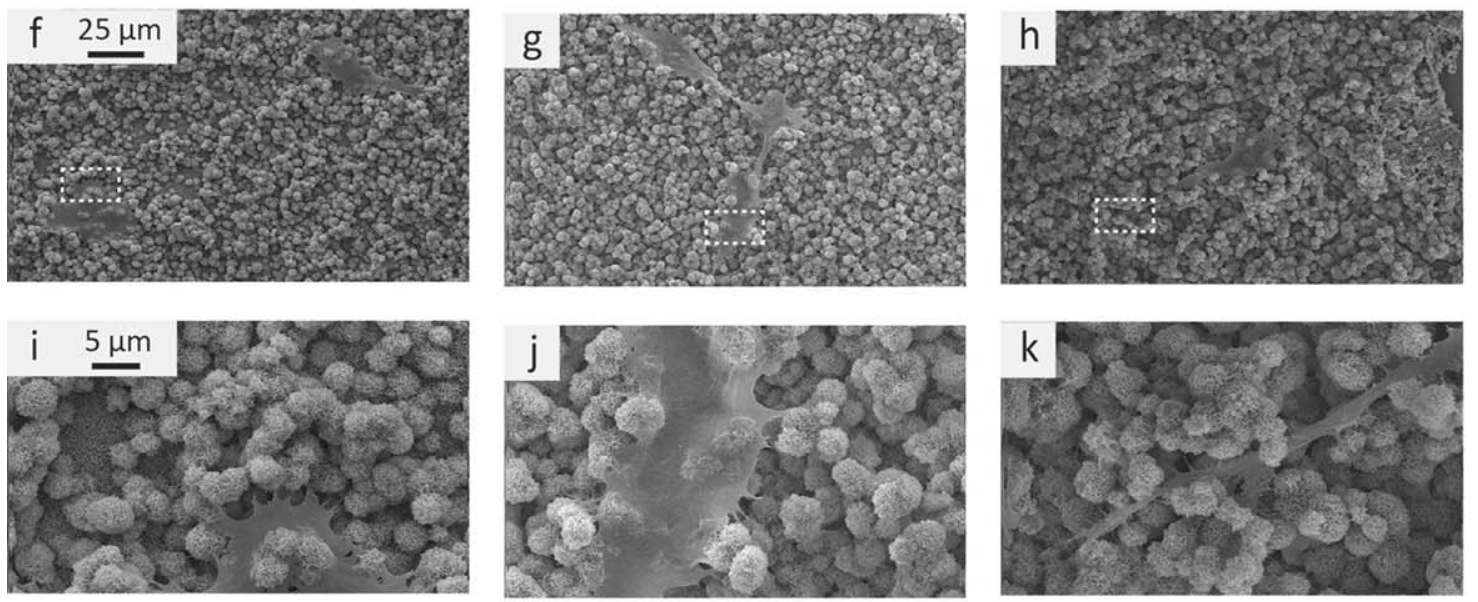

I

$\mathrm{m}$
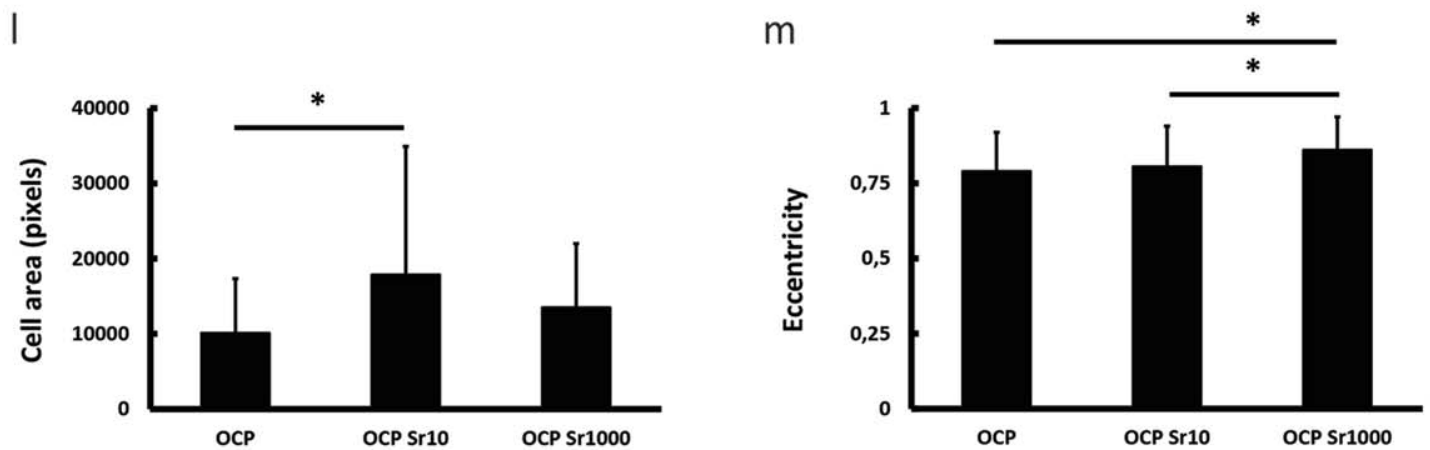

FIGURE 3. Fluorescent microscopy images of the cells cultured for 1 day on TCPs in basic medium without 0 (a), and supplemented with 10 (b) or 1000 (c) $\mu \mathrm{M} \mathrm{Sr}^{2+}$, quantification of cell area (d) and eccentricity (e) of these cells, SEM images of the cells cultured for 1 day in basic medium on OCP (f), OCP Sr10 (g), and OCP Sr1000 (h) coatings with (i-k) magnified images of the areas marked with dashed lines in (f-h) images, respectively, and quantification of cell area (I) and eccentricity $(\mathrm{m})$ of these cells. In fluorescent images, the cells were stained with Dapi (in blue) and Phalloidin (in green) showing cell nuclei and cytoskeleton, respectively. Cells cultured with $1000 \mu \mathrm{M} \mathrm{Sr}^{2+}$ appeared to have a higher aspect ratio compared with cells cultured without $\mathrm{Sr}^{2+}$ and with addition of $10 \mu \mathrm{M} \mathrm{Sr}{ }^{2}$. Cells cultured on OCP Sr1000 coatings were more elongated compared with the cells cultured on OCP and OCP Sr10 coatings. Quantification of eccentricity of the cells confirms these results. 
a

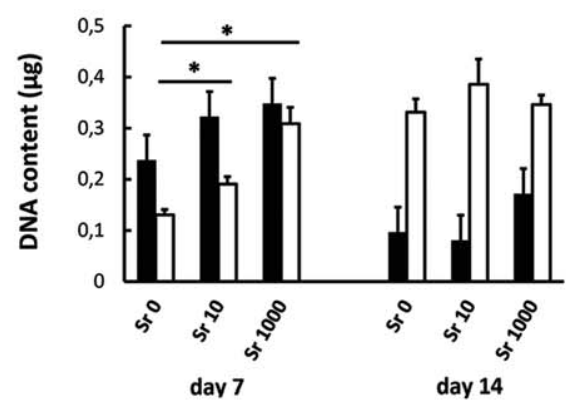

C
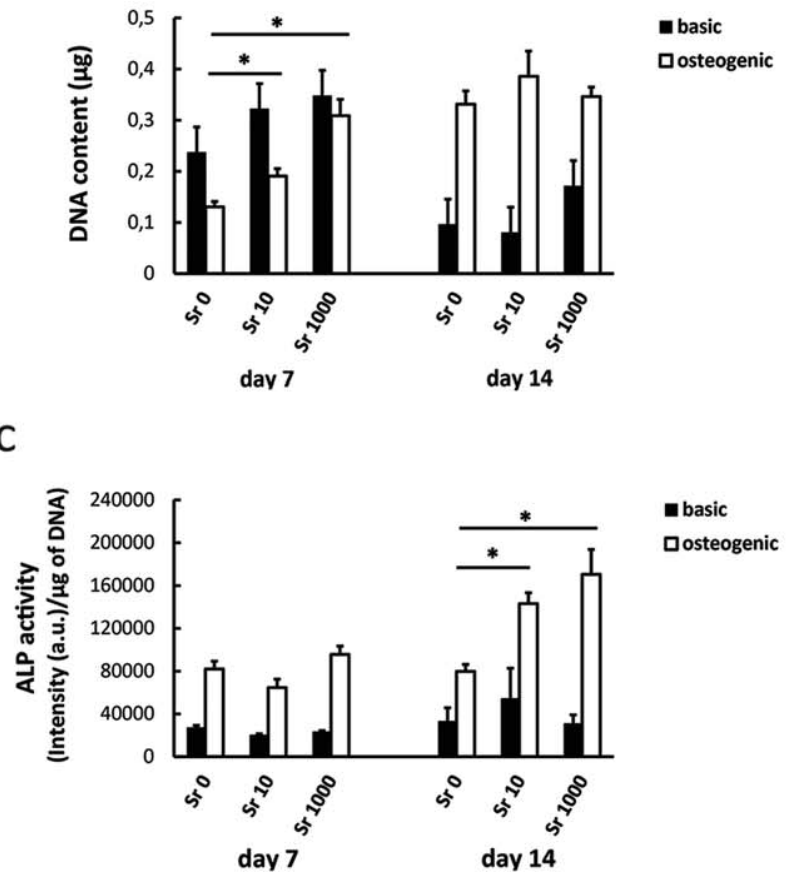

b

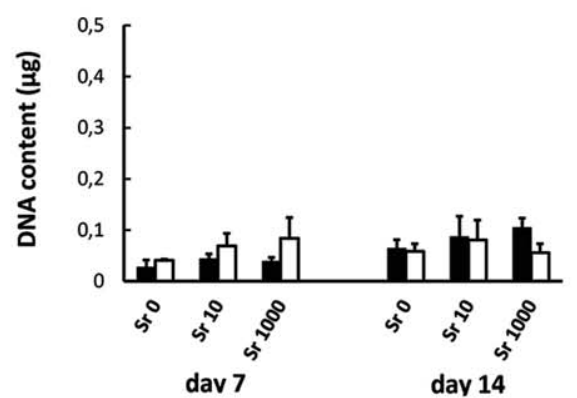

- basic

Dosteogenic

d

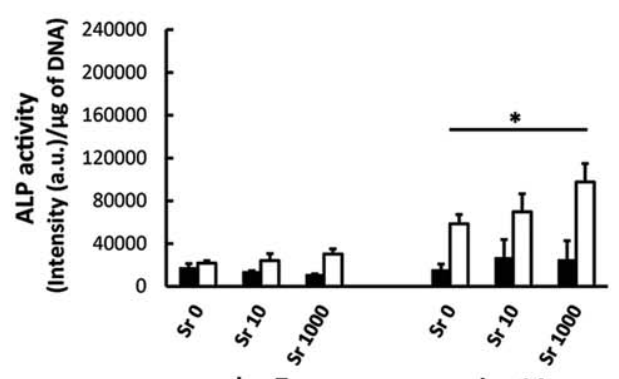

a basic

口osteogenic

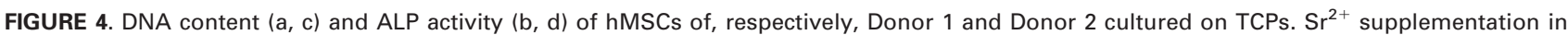
cell culture medium slightly increased the DNA content of the Donor 1 cells at day 7 , while no differences were observed for the other conditions. At day 14, addition of $\mathrm{Sr}^{2+}$ to osteogenic medium resulted in increasing ALP activity of hMSCs in a dose-dependent manner.

donor 1

a

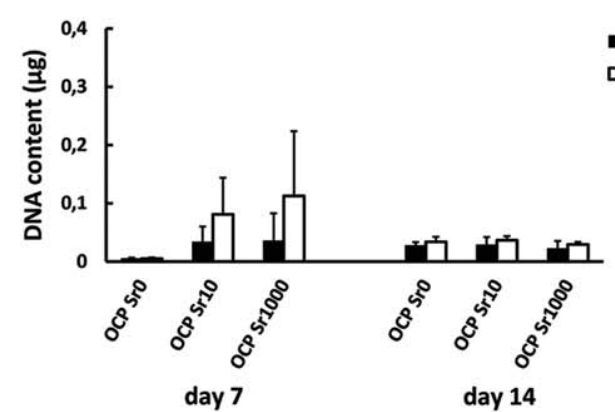

C
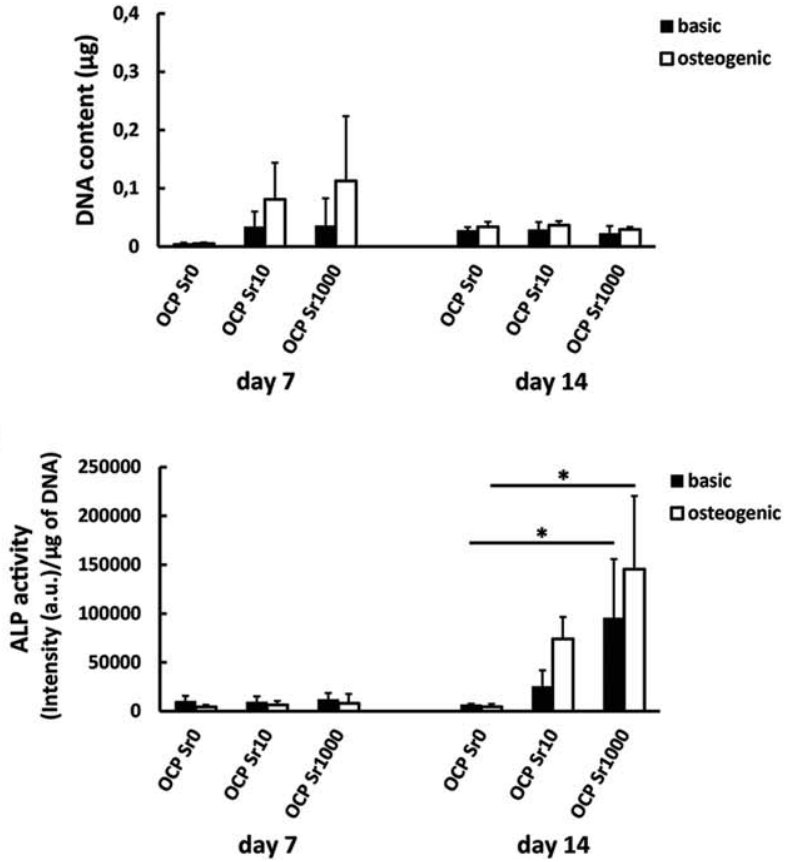

b

d

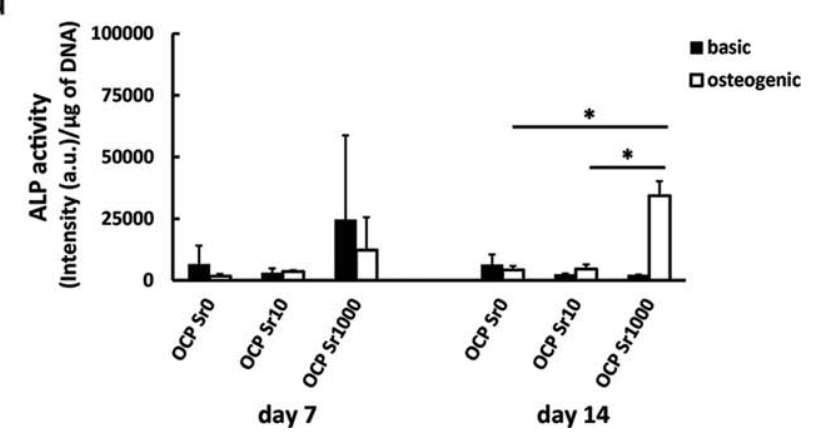

FIGURE 5. DNA content (a, c) and ALP activity (b, d) of hMSCs of, respectively, Donor 1 and Donor 2 cultured on the coatings. At day 14 , an increase in DNA content of the cells of Donor 2 was observed upon incorporation of $\mathrm{Sr}^{2+}$ into the coatings. At day 14 , addition of $\mathrm{Sr}^{2+}$ to either medium in cultures of Donor 1 cells and to osteogenic medium in cultures of Donor 2 cells resulted in an increase in ALP activity in a strontium dose-dependent manner. 
days, the addition of $\mathrm{Sr}^{2+}$ to osteogenic media increased the ALP expression, however, this effect was not consistent between the donors [Fig. 6(a,b)].

At day 7, no differences among the conditions were observed in the bone sialoprotein (BSP) expression when cells were cultured on TCPs in basic medium. However, at day $14, \mathrm{Sr}^{2+}$ supplementation in both basic and osteogenic media resulted in an ascending trend in expression of BSP dependent on $\mathrm{Sr}^{2+}$ dose, with a significant effect in osteogenic medium in donor 1 and in basic medium in donor 2 cells [Fig. 6(c,d)].

At days 7 and 14, the addition of $\mathrm{Sr}^{2+}$ to basic media only appeared to influence bone morphogenetic protein 2 (BMP2) expression, however, this result was statistically significant only between 0 and $1000 \mu M$ in Donor 1 , and 10 and $1000 \mu M$ in Donor 2. A similar trend was observed in osteopontin (OP) expression in basic media, with significant difference between 10 and $1000 \mu M$ in Donor 2 cells. The addition of $1000 \mu M$ to osteogenic media significantly increased OP expression in Donor 1, however, this result was not observed in Donor 2 cells [Fig. 6(e,f)].

No significant differences among the conditions were observed in $\mathrm{OC}$ expression at 7 days in either medium. At day 14 , the addition of $\mathrm{Sr}^{2+}$ to both basic and osteogenic media appeared to decrease OC expression in a dose dependent manner in donor 1; however, this result was statistically significant only in osteogenic medium. Unlike in Donor 1 cells, the OC expression by the cells of Donor 2 was significantly increased upon addition of $1000 \mu M$ of $\mathrm{Sr}^{2+}$ to basic medium at day 14 , while no effect was seen in osteogenic medium [Fig. 6(g-j)].

At day 14, hMSCs of donor 1 only, cultured on OCP Sr1000 expressed slightly higher ALP mRNA levels compared with the cells cultured on OCP and OCP Sr10 in basic medium. A similar effect was detected in osteogenic medium, however, this was only significant between OCP and OCP Sr1000. [Fig. 7(a,b)].

Differences in the expression of BSP of cells cultured on different coatings were only observed for Donor 1 . At days 7 and 14, incorporation of $\mathrm{Sr}^{2+}$ into OCP coatings increased the expression of BSP in basic medium in a dose-dependent manner [Fig. 7(c,d)].

While low BMP2 levels were observed for all conditions in osteogenic medium, at day 14, hMSCs of donor 1 cultured on OCP Sr1000 coating showed higher BMP2 expression compared to the ones cultured on OCP and OCP Sr10 in basic medium. A similar effect, however not significant, was observed in donor 2 as well [Fig. 7(e,f)].

Similar to BMP2, expression of OP was low in osteogenic medium in all the conditions. At day 14, expression of OP in basic medium was higher in OCP Sr1000 coatings compared to OCP and OCP Sr10 in donor 1. A similar, but nonsignificant effect was observed in donor 2 at similar conditions [Fig. $7(\mathrm{~g}, \mathrm{~h})]$.

While at 7 days, no significant differences were observed, at day 14, in donor 1, higher OC levels were seen in both media when cells were cultured on OCP Sr1000 coatings compared to OCP and OCP Sr10, however, in basic medium this effect was only significant between OCP Sr1000 and OCP Sr10. In donor 2, OC was upregulated in osteogenic medium in the cells cultured on OCP Sr1000 compared to the cells cultured on OCP and OCP Sr10 [Fig. $7(\mathrm{i}, \mathrm{j})]$.

\section{Ion concentrations in cell medium}

Concentrations of $\mathrm{Ca}^{2+}$ and $\mathrm{Sr}^{2+}$ ions in basic medium up to day 7 were measured using ICP-MS (Table IV). $\mathrm{Ca}^{2+}$ content of control cell culture medium, not containing cells or coatings, slightly decreased after 2 days. However, this concentration reached the original values at later time points. A major decrease of $>1 \mu M$ in $\mathrm{Ca}^{2+}$ content of cell medium incubated with $\mathrm{CaP}$ coatings cultured with cells was detected after 2 days of culture. $\mathrm{Ca}^{2+}$ content of the medium remained constant at this level at later time points. This effect was independent of $\mathrm{Sr}^{2+}$ incorporation.

$\mathrm{A} \mathrm{Sr}^{2+}$ release of $\sim 12 \mu \mathrm{M}$ was observed in cell medium conditioned with OCP Sr1000 $\mu M$ after 2 days. The $\mathrm{Sr}^{2+}$ release was calculated as $\sim 5$ and $2 \mu M$ for 4 and 7 days, respectively. The $\mathrm{Sr}^{2+}$ release was negligible in the medium conditioned with OCP and OCP Sr10 samples.

\section{DISCUSSION}

Among the trace elements within bone mineral, strontium is of particular interest due to its reported osteogenic and antiresorptive effects. ${ }^{16,17}$ Pasqualetti et al. suggested that, while absolute levels of strontium influence the embryonic mineralization, the actual strontium-to-calcium ratio may also have an important role in the mineralization process. ${ }^{39}$ In addition to the chemical interplay, strontium has been suggested to influence cellular responses by affecting the physicochemical properties of the mineral. ${ }^{11}$ In this manner, strontium ranelate is thought to prevent osteoporotic fractures via an increase in bone hardness due to the $\mathrm{Sr}^{2+}$ ionic substitution. ${ }^{40,41}$ To further develop strontium-based treatments, the exact mechanisms of strontium's actions are yet to be fully elucidated.

In this study, a biomimetic approach was taken to prepare strontium-incorporated $\mathrm{CaP}$ coatings on Ti substrates. The results indicated that a predominantly crystalline OCP layer formed which was not inhibited by the lower concentration of strontium, though the crystal morphology was influenced at higher strontium concentrations. The presence of strontium was confirmed using EDS and ICP-MS analyses. The decrease in the $\mathrm{Ca} / \mathrm{P}$ ratio, and increase in the $\mathrm{Sr} / \mathrm{P}$ ratio, with a constant $(\mathrm{Ca}+\mathrm{Sr}) / \mathrm{P}$ ratio of 1.2 were observed. While the calculated ratio of $\mathrm{Ca} / \mathrm{P}$ of 1.2 in this study differs to the theoretical OCP value of 1.33 , this value may have been affected by the semi-quantitative nature of the elemental analysis used. Additionally, the FTIR data indicated the presence of carbonate bands, suggesting the coating formed was not phase-pure. Further, when compared to the coatings formed in absence of $\mathrm{Sr}^{2+}$ ions, the small shift to smaller angles was observed in the XRD pattern of OCP Sr1000 coatings, which may be due to the incorporation of strontium ions into the OCP lattice, as shown earlier. ${ }^{42}$ This 
donor 1

a

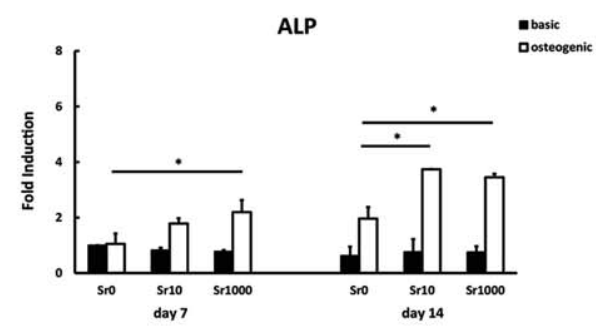

C

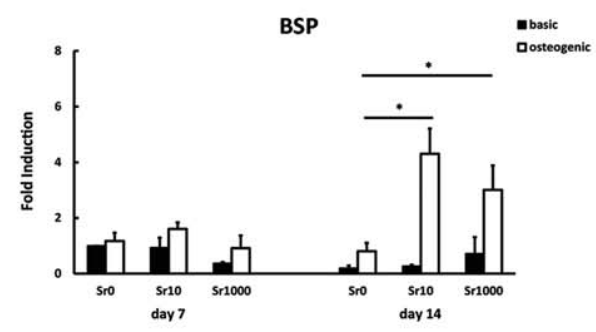

e

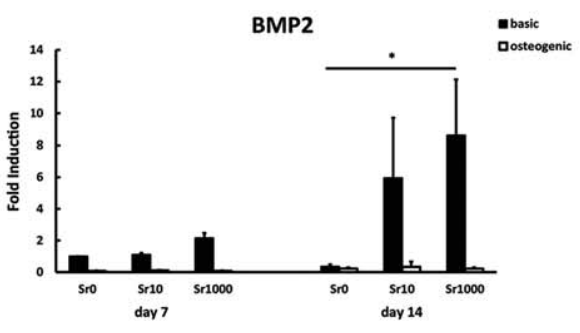

g

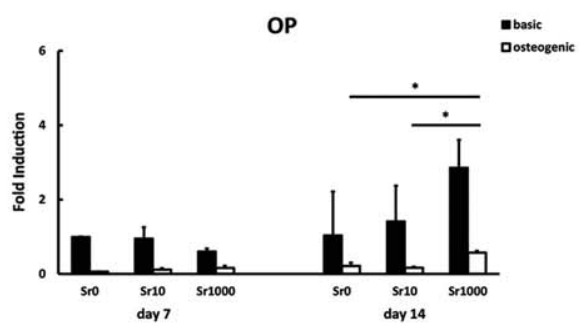

i

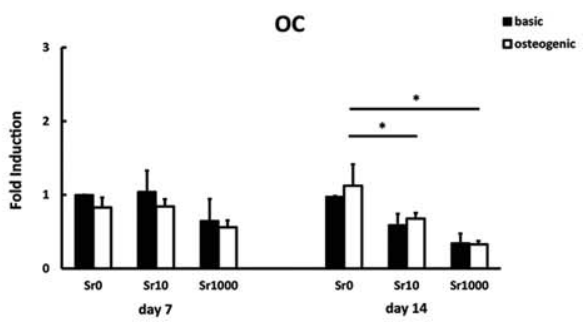

b

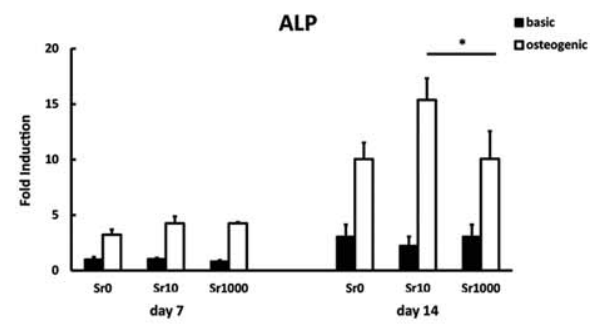

d

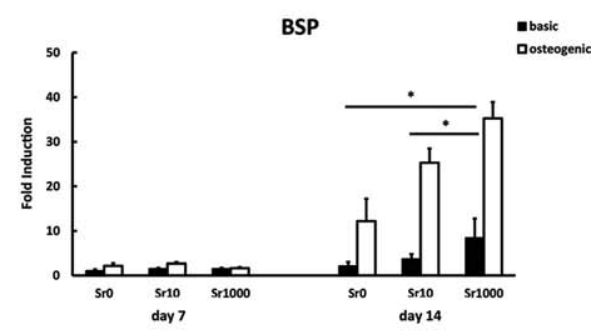

f

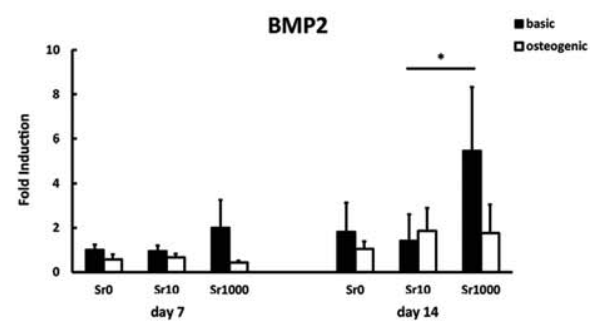

h

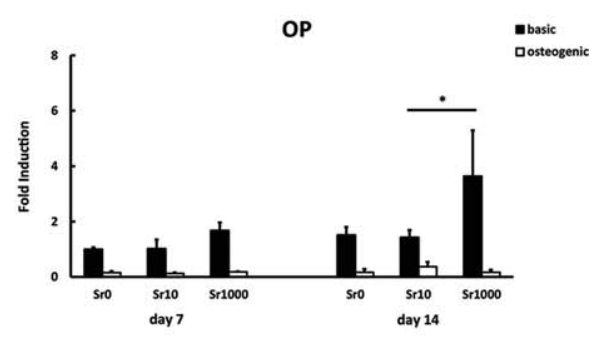

j

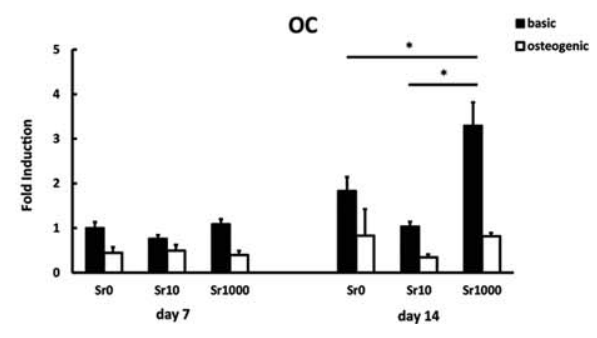

FIGURE 6. mRNA expression of ALP $(a, b), B S P(c, d), B M P 2(e, f)$, OP $(g, h)$, and OC $(i, j)$ by, respectively, hMSCs of Donor 1 and Donor 2 cultured on TCPs. The results are normalized for the MRNA level of GAPDH as a housekeeping gene and calibrated for the mRNA level of each gene of hMSCs cultured in basic medium without supplementation for 7 days. mRNA expression of all the osteogenic markers was altered upon addition of $\mathrm{Sr}^{2+}$ to cell culture medium. $\mathrm{Sr}^{2+}$ ions generally increased the expression of ALP, BSP, BMP2, and OP, with comparable trends in both donors. Opposing trends were, however, observed in the expression of OC from Donor 1 and Donor 2 cells. 
donor 1

a

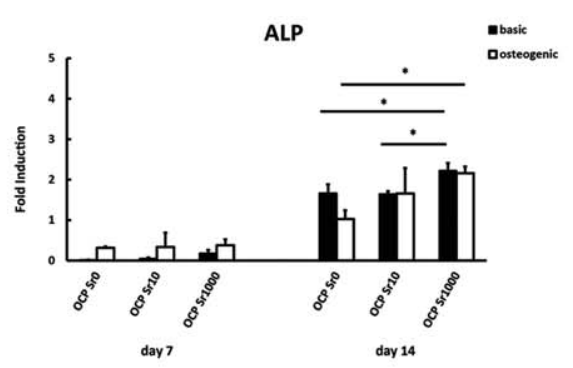

C

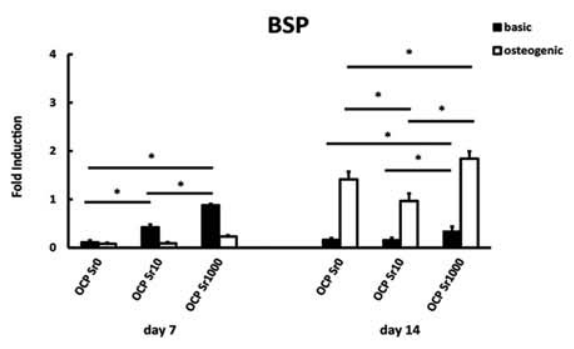

e

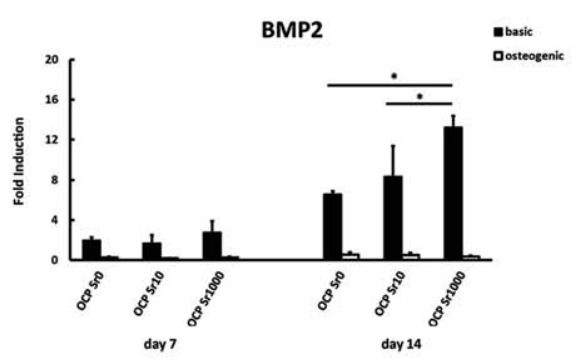

g

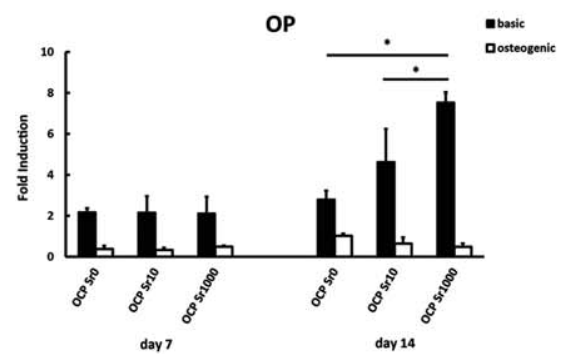

i

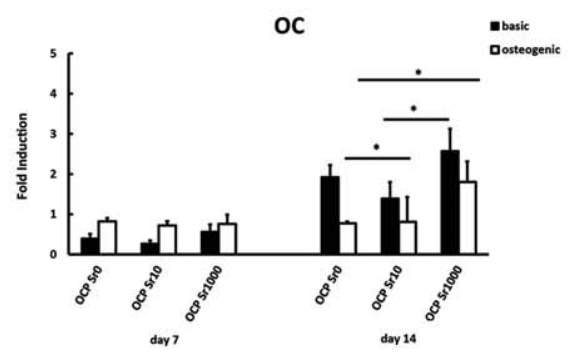

b

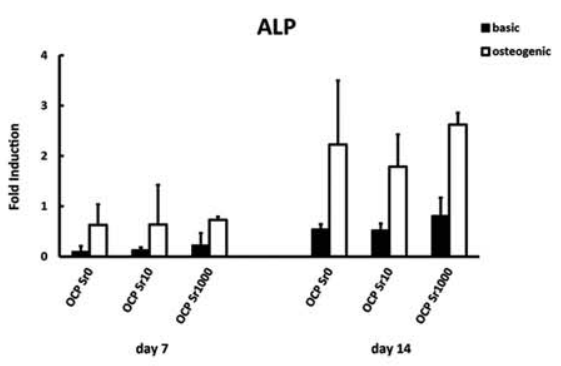

d

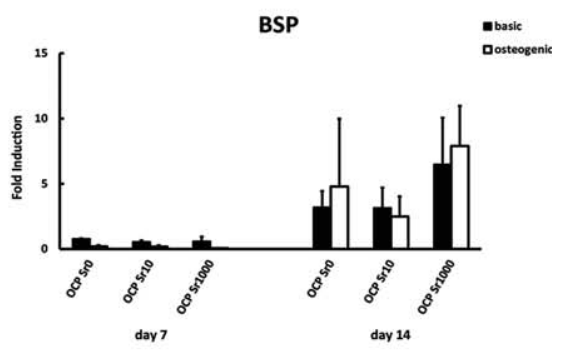

f

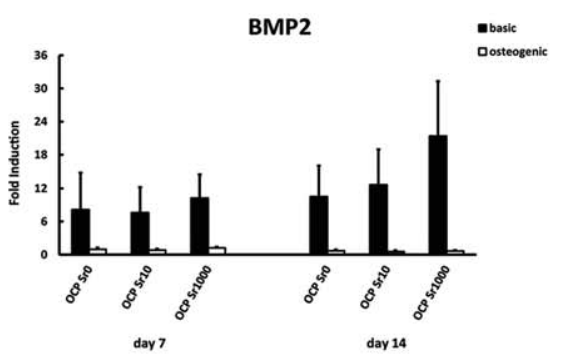

h

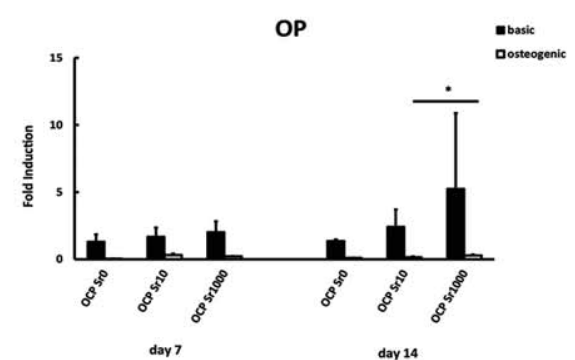

j

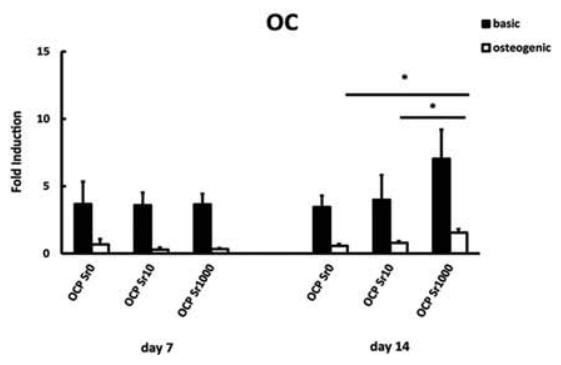

FIGURE 7. mRNA expression of ALP (a,b), BSP $(c, d), B M P 2(e, f)$, OP $(g, h)$, and OC $(i, j)$ by respectively hMSCs of Donor 1 and Donor 2 cultured on CaP coatings. The results are normalized for the mRNA level of GAPDH as a housekeeping gene and calibrated for the mRNA level of each gene in hMSCs cultured in basic medium on OCP coating for 7 days. In general, presence of $\mathrm{Sr}^{2+}$ in the CaP coatings positively affected the expression of osteogenic markers. Similar trends were observed in the two donors, with the effects being stronger in Donor 1 cells. 
TABLE IV. $\mathrm{Ca}^{2+}$ and $\mathrm{Sr}^{2+}$ Concentration of Basic Medium Collected During the Culture of hMSCs on CaP Coatings with, as a Control, Basic Medium Without Materials or Cells

\begin{tabular}{|c|c|c|c|c|c|c|c|c|}
\hline \multirow[b]{2}{*}{ Day } & \multirow[b]{2}{*}{$\begin{array}{c}\mathrm{Ca}^{2+} \\
\text { Content }\end{array}$} & \multirow[b]{2}{*}{$\begin{array}{c}\mathrm{Sr}^{2+} \\
\text { Content }\end{array}$} & \multicolumn{2}{|c|}{ OCP SrO } & \multicolumn{2}{|c|}{ OCP Sr10 } & \multicolumn{2}{|c|}{ OCP Sr1000 } \\
\hline & & & $\begin{array}{c}\mathrm{Ca}^{2+} \\
\text { Content }\end{array}$ & $\begin{array}{c}\mathrm{Sr}^{2+} \\
\text { Content }\end{array}$ & $\begin{array}{c}\mathrm{Ca}^{2+} \\
\text { Content }\end{array}$ & $\begin{array}{c}\mathrm{Sr}^{2+} \\
\text { Content }\end{array}$ & $\begin{array}{c}\mathrm{Ca}^{2+} \\
\text { Content }\end{array}$ & $\begin{array}{c}\mathrm{Sr}^{2+} \\
\text { Content }\end{array}$ \\
\hline 0 & 1720.50 & 0.55 & 1720.50 & 0.55 & 172.50 & 0.55 & 1720.50 & 0.55 \\
\hline 2 & 1226.97 & 0.57 & 790.99 & 0.33 & 769.39 & 0.48 & 820.54 & 12.22 \\
\hline 4 & 1373.85 & 0.61 & 773.75 & 0.34 & 707.84 & 0.40 & 735.46 & 5.02 \\
\hline 7 & 1757.04 & 0.69 & 769.44 & 0.60 & 714.88 & 0.37 & 770.47 & 3.22 \\
\hline
\end{tabular}

A decrease of $\mathrm{Ca}^{2+}$ concentration was observed after 2 days in all the samples, after which a plateau at about $700 \mu \mathrm{M}$ was reached. A release of 12,5 , and $3 \mu \mathrm{M} \mathrm{Sr}{ }^{2+}$ after 2,4 , and 7 days, respectively, was detected during cell culture of OCP Sr1000, suggesting dissolution/reprecipitation events occurring on the coating surface.

shift however may also be due to broadening of the diffraction peaks upon addition of the $\mathrm{Sr}^{2+}$ or the overall structural change toward a more apatitic phase resulting in modification of the XRD pattern. Therefore, physical entrapment of strontium acetate or another strontium salt into the coating during deposition cannot be fully excluded. Regardless, this data proved the formation of an OCP phase with varying $\mathrm{Sr}^{2+}$ content, which was directly dependent on the impregnation concentration of $\mathrm{Sr}^{2+}$.

The results indicated a release of strontium from OCP Sr1000 coatings into basic cell medium at 12,5 , and $3 \mu M$ after 2, 4, and 7 days, respectively. A relatively high release of $\mathrm{Sr}^{2+}$ after 2 days was accompanied by a pronounced uptake of $\mathrm{Ca}^{2+}$ ions from the medium, while at the later time points, the $\mathrm{Ca}^{2+}$ concentration remained constant, and release of $\mathrm{Sr}^{2+}$ decreased. This may have been due to reprecipitation of a new biological apatite layer formed through dissolution/reprecipitation events occurring on the coating surface. $^{43}$ The maximum amount of strontium in the prepared OCP coatings was $\sim 8.9 \%$ of the calcium content, which aligns with the percentage reported for a similar method of production. ${ }^{11}$ These values are also in the range reported for that of human bone, being 3.9 at $\% .{ }^{44}$ However, due to ion release via CaP dissolution, it is difficult to relate total incorporated percentage to the actual ion concentration exposed to the cell.

Cytoskeletal components such as actin have been reported to be involved in mediating hMSC proliferation and differentiation toward osteogenic lineage, with early cytoskeletal organization reportedly having a major effect on cell fate. ${ }^{45}$ Barradas et al., ${ }^{46}$ for example, have shown that the $\mathrm{Ca}^{2+}$ induced morphological changes initially occurred in the cytoskeleton as early as after $12 \mathrm{~h}$. Therefore, we have selected a $24 \mathrm{~h}$ time point for studying the early morphological organization induced by $\mathrm{Sr}^{2+}$.

The presence of strontium appeared to influence cell shape, with a more elongated morphology observed as compared to cells cultured in absence of strontium. In particular, a dose-dependent effect on cell eccentricity was detected upon increasing strontium concentration. Similar changes in eccentricity have previously been identified as important parameters for interpreting changes in cellular responses. ${ }^{35}$ In this study, elongated cells generally corresponded to a higher expression of osteogenic markers at
mRNA level. While changes in cell morphology are often considered to relate to cell fate, the morphology corresponding to specific lineages remains uncertain. ${ }^{45-48}$ As such, while shape differences were noted in this study, further investigation is needed to provide a more detailed context for these results.

A different trend in the changes in cell area as a function of $\mathrm{Sr}^{2+}$ content was observed on TCPs as compared to the CaP coatings. This could in a part be explained by lower levels of $\mathrm{Sr}^{2+}$ released from the coatings, as compared to the $\mathrm{Sr}^{2+}$ conditioned media. Furthermore, the cell microenvironment provided by the CaP coatings included the presence of other ions, as well as the topographical cues of the substrate surface, which is substantially different from that of the cultures on TCPs.

The addition of strontium appeared to influence the DNA production of hMSCs, which is considered an indicator of cell proliferation. However, these changes were relatively small, being less than two-fold. $\mathrm{Sr}^{2+}$ ions have previously shown to increase the proliferation of human osteoblasts, ${ }^{49}$ and increase the production of collagen matrix in murine preosteoblast cells. ${ }^{50}$ Therefore, enhancing the proliferation and survival of bone forming cells has been proposed as a mechanism in which $\mathrm{Sr}^{2+}$ favors bone formation. ${ }^{4,51}$ While the results did not reject this hypothesis, this study could did not strongly support this statement.

ALP enzyme activity of hMSCs was generally increased upon exposure to $\mathrm{Sr}^{2+}$ ions via both delivery methods, although there was some variation between donors. This finding is consistent with previously reported data. ${ }^{25-27,49,50}$

The effect of strontium on the expression of osteogenic markers at the mRNA level appeared to be dose dependent. This suggests that within the limits of this study, a higher dose of strontium used was favorable. This result aligns with previously published data, in which strontium was reported to have a dose dependent effect on the ALP activity of hMSCs. ${ }^{27,49,52}$ Similarly, Brennan et al. $^{49}$ and Bonnelye et $a l^{16}$ detected the biologic effects of $\mathrm{Sr}^{2+}$ in the form of strontium ranelate on osteogenic markers at a minimum concentration of $1000 \mu M$. Therefore, strontium release and dose should be considered in future strategies.

The expression of osteogenic markers was also highly dependent on the medium used. Generally, expression of BMP2, OP, and OC was higher in basic medium, whereas 
ALP and BSP genes were more highly expressed in osteogenic medium. The osteogenic medium used in this study contained $10 \mathrm{n} M$ dexamethasone, a concentration previously shows to be optimal for formation of mineralized nodules in human osteoblast precursor cell culture. ${ }^{53}$ At this concentration, dexamethasone has also been reported to increase the expression of ALP and RUNX2 of human primary bone cells at mRNA and protein level. ${ }^{46,53-55}$ Conversely, evidence exists for the negative effects of glucocorticoids, such as dexamethasone, on bone mineralization, which may lead to lower bone mineral density. ${ }^{56}$ Wiontzek et al. also demonstrated the inhibitory effects of dexamethasone, in which intracellular $\mathrm{Ca}^{2+}$ concentration increased in MG63 shortly after dexamethasone treatment. ${ }^{57}$ It appears that in this study, the addition of dexamethasone to cell medium inhibited the regulatory effects of $\mathrm{Ca}^{2+}$, resulting in downregulation of $\mathrm{Ca}^{2+}$-dependent osteogenic markers including BMP2, OP and OC. ${ }^{46} \mathrm{Sr}^{2+}$ ions, as a divalent cation similar to $\mathrm{Ca}^{2+}$, may act on similar cellular targets as $\mathrm{Ca}^{2+}$, and similar effects are expected to occur. ${ }^{46}$

Generally, hMSCs cultured on OCP coatings with and without Sr incorporation had a higher expression of BMP2, OP, and OC, and lower expression of ALP and BSP, when compared cells cultured on TCPs in Sr-supplemented media. This is likely due to the regulatory effects of $\mathrm{Ca}^{2+}$ ions on BMP2, OP, and OC expression. The $\mathrm{Ca}^{2+}$ level in cell medium containing the different coatings was similar and independent of $\mathrm{Sr}^{2+}$ incorporation, while the $\mathrm{Sr}^{2+}$ concentration differed, which may explain differences in the expression of the osteogenic markers in coatings with and without strontium and suggests the combined effects of both ions. This is further highlighted by the fact that, while the medium concentration of strontium was similar between the OCP Sr1000 and $10 \mu M \mathrm{Sr}^{2+}$ supplemented media, the hMSC response in these conditions was very different. The expression of BMP2, OP, and OC in OCP Sr1000 was substantially higher than that for the cells cultured with 10 and $1000 \mu M$ $\mathrm{Sr}^{2+}$ salt, indicating a combinatory effect of strontium and calcium ions on the osteogenic markers, which are known to be $\mathrm{Ca}^{2+}$-dependent. As expected, such an effect was not observed on ALP and BSP expression, even when the presence of strontium in the coatings resulted in upregulating these genes.

It is worth mentioning that the expression of the osteogenic markers at mRNA level does not necessarily translate to production of these proteins. Therefore, the study of the effects of $\mathrm{Sr}^{2+}$ addition to the CaPs on production of the osteogenic matrix proteins is recommended for future experiments.

It should be noted that changes in calcium content of the medium in presence of OCP coating are expected to be accompanied by the changes in inorganic phosphate concentration, also known to affect the hMSCs behavior ${ }^{58}$ and this effect needs further investigation. Furthermore, possible direct effects of changes in crystal structure upon incorporation of strontium into the coating require further investigation, since the cell fate can be affected by the physical properties of the material surface, ${ }^{59}$ such as roughness, microporosity and macroporosity, ${ }^{60}$ grain size, ${ }^{61}$ and topography. ${ }^{49,50,62}$

\section{CONCLUSION}

This study confirms that strontium promotes the osteogenic differentiation of bone marrow derived hMSCs, when introduced to the cells as either dissolved salt or incorporated into CaP coatings. Importantly, the positive effect of strontium appears to synergistically increase when used in combination with CaP coatings. Overall, this study supports the use of $\mathrm{Sr}^{2+}$-incorporated CaPs as potential synthetic bone graft substitutes.

\section{ACKNOWLEDGMENTS}

This research forms part of the Project P2.04 BONE-IP of the research program of the BioMedical Materials institute. Authors thank Professor Marc Bohner, Benjamin Andreatta, and Reto Luginbuhl from the RMS Foundation, Switzerland, for collaboration in conducting ICP-MS measurements and critical reading of the manuscript.

\section{REFERENCES}

1. Braux J, Velard F, Guillaume C, Bouthors S, Jallot E, Nedelec J, Laurent-Maquin D, Laquerrière P. A New Insight into the Dissociating Effect of Strontium on Bone Resorption and Formation. Acta Biomater 2011;7:2593-2603.

2. Bohner M, Galea L, Doebelin N. Calcium Phosphate Bone Graft Substitutes: Failures and Hopes. J Eur Ceram Soc 2012;32:26632671.

3. Bigi A, Cojazzi G, Panzavolta S, Ripamonti A, Roveri N, Romanello M, Noris Suarez K, Moro L. Chemical and Structural Characterization of the Mineral Phase from Cortical and Trabecular Bone. J Inorg Biochem 1997;68:45-51.

4. Yang L, Harink B, Habibovic P. Calcium Phosphate Ceramics with Inorganic Additives. Elsevier; Amsterdam, Netherlands 2011. p 229-312.

5. Vo TN, Kurtis Kasper F, Mikos AG. Strategies for Controlled Delivery of Growth Factors and Cells for Bone Regeneration. Adv Drug Delivery Rev 2012;64:1292-1309.

6. Liu Y, de Groot K, Hunziker EB. BMP-2 Liberated from Biomimetic Implant Coatings Induces and Sustains Direct Ossification in an Ectopic Rat Model. Bone 2005;36:745-757.

7. Malhotra A, Pelletier M, Oliver R, Christou C, Walsh WR. PlateletRich Plasma and Bone Defect Healing. Tissue Eng Part A 2014;20: 2614-2633.

8. Jäger M, Hernigou P, Zilkens C, Herten M, Li X, Fischer J, Krauspe R. Cell Therapy in Bone Healing Disorders. Orthop Rev 2010;2:79-87.

9. Mooney DJ, Vandenburgh H. Cell Delivery Mechanisms for Tissue Repair. Cell Stem Cell 2008;2:205-213.

10. Boanini E, Gazzano M, Bigi A. Ionic Substitutions in Calcium Phosphates Synthesized at Low Temperature. Acta Biomater 2010;6:1882-1894.

11. Yang L, Perez-Amodio S, Barrère-de Groot FY, Everts V, van Blitterswijk CA, Habibovic P. The Effects of Inorganic Additives to Calcium Phosphate on In Vitro Behavior of Osteoblasts and Osteoclasts. Biomaterials 2010;31:2976-2989.

12. Hoppe A, Güldal NS, Boccaccini AR. A Review of the Biological Response to Ionic Dissolution Products from Bioactive Glasses and Glass-ceramics. Biomaterials 2011;32:2757-2774.

13. Habibovic $P$, Barralet JE. Bioinorganics and Biomaterials: Bone Repair. Acta Biomater 2011;7:3013-3026.

14. Meunier PJ, Roux C, Seeman E, Ortolani S, Badurski JE, Spector TD, Cannata J, Balogh A, Lemmel EM, Pors-Nielsen S. The Effects of Strontium Ranelate on the Risk of Vertebral Fracture in Women with Postmenopausal Osteoporosis. N Engl J Med 2004;350:459468. 
15. O'donnell S, Cranney A, Wells G, Adachi J, Reginster JY. Strontium Ranelate for Preventing and Treating Postmenopausa Osteoporosis. Cochrane Database Syst Rev 2006;4:CD005326.

16. Bonnelye E, Chabadel A, Saltel F, Jurdic P. Dual Effect of Strontium Ranelate: Stimulation of Osteoblast Differentiation and Inhibition of Osteoclast Formation and Resorption In Vitro. Bone 2008;42:129-138.

17. Marie PJ. Strontium Ranelate: A Dual Mode of Action Rebalancing Bone Turnover in Favour of Bone Formation. Curr Opin Rheumatol 2006;18:S11-S15.

18. Sabareeswaran A, Basu B, Shenoy SJ, Jaffer Z, Saha N, Stamboulis A. Early Osseointegration of a Strontium Containing Glass Ceramic in a Rabbit Model. Biomaterials 2013;34:9278-9286.

19. Gentleman E, Fredholm YC, Jell G, Lotfibakhshaiesh N, O'Donnel MD, Hill RG, Stevens MM. The Effects of Strontium-Substituted Bioactive Glasses on Osteoblasts and Osteoclasts In Vitro. Biomaterials 2010;31:3949-3956.

20. Zhang J, Zhao S, Zhu Y, Huang Y, Zhu M, Tao C, Zhang C. ThreeDimensional Printing of Strontium-Containing Mesoporous Bioactive Glass Scaffolds for Bone Regeneration. Acta Biomater 2014; 10:2269-2281.

21. Andersen $O Z$, Offermanns $V$, Sillassen $M$, Almtoft KP, Andersen $I H$, Sørensen S, Jeppesen CS, Kraft DCE, Bøttiger J, Rasse M, Kloss F, Foss M. Accelerated Bone Ingrowth by Local Delivery of Strontium from Surface Functionalized Titanium Implants. Biomaterials 2013;34:5883-5890.

22. Zhao L, Wang H, Huo K, Zhang $X$, Wang W, Zhang $Y$, Wu Z, Chu PK. The osteogenic Activity of Strontium Loaded Titania Nanotube Arrays on Titanium Substrates. Biomaterials 2013;34:19-29.

23. Lin $\mathrm{K}$, Xia L, Li H, Jiang $X$, Pan $\mathrm{H}, \mathrm{Xu} \mathrm{Y,} \mathrm{Lu} \mathrm{WW,} \mathrm{Zhang} Z$, Chang J. Enhanced Osteoporotic Bone Regeneration by StrontiumSubstituted Calcium Silicate Bioactive Ceramics. Biomaterials 2013;34:10028-10042.

24. Singh S, Roy A, Lee BE, Ohodnicki J, Loghmanian A, Banerjee I, Kumta PN. A Study of Strontium Doped Calcium Phosphate Coatings on AZ31. Mater Sci Eng A 2014;40:357-365.

25. Zhang W, Shen $Y$, Pan H, Lin K, Liu X, Darvell BW, Lu WW, Chang J, Deng L, Wang D, Huang W. Effects of Strontium in Modified Biomaterials. Acta Biomater 2011;7:800-808.

26. Boanini E, Torricelli P, Fini M, Sima F, Serban N, Mihailescu IN, Bigi A. Magnesium and Strontium Doped Octacalcium Phosphate Thin Films by Matrix Assisted Pulsed Laser Evaporation. J Inorg Biochem 2012;107:65-72.

27. Capuccini C, Torricelli P, Sima F, Boanini E, Ristoscu C, Bracci B, Socol G, Fini M, Mihailescu IN, Bigi A. Strontium-Substituted Hydroxyapatite Coatings Synthesized by Pulsed-Laser Deposition: In Vitro Osteoblast and Osteoclast Response. Acta Biomater 2008; 4:1885-1893.

28. Thormann U, Ray S, Sommer U, ElKhassawna T, Rehling T, Hundgeburth M, Henß A, Rohnke M, Janek J, Lips KS, Heiss C Schlewitz G, Szalay G, Schumacher M, Gelinsky M, Schnettler R, Alt V. Bone Formation Induced by Strontium Modified Calcium Phosphate Cement in Critical-Size Metaphyseal Fracture Defects in Ovariectomized Rats. Biomaterials 2013;34:8589-8598.

29. Li Y, Li Q, Zhu S, Luo E, Li J, Feng G, Liao Y, Hu J. The Effect of Strontium-Substituted Hydroxyapatite Coating on Implant Fixation in Ovariectomized Rats. Biomaterials 2010;31:9006-9014.

30. Ni GX, Chiu KY, Lu WW, Wang Y, Zhang YG, Hao LB, Li ZY, Lam WM, Lu SB, Luk KDK. Strontium-Containing Hydroxyapatite Bioactive Bone Cement in Revision Hip Arthroplasty. Biomaterials 2006;27:4348-4355.

31. Patntirapong $S$, Habibovic $P$, Hauschk PV. Effects of Soluble Cobalt and Cobalt Incorporated into Calcium Phosphate Layers on Osteoclast Differentiation and Activation. Biomaterials 2009:30:548-555.

32. Fernandes $H$, Mentink A, Bank $R$, Stoop $R$, van Blitterswijk $C$, de Boer J. Endogenous Collagen Influences Differentiation of Human Multipotent Mesenchymal Stromal Cells. Tissue Eng Part A 2010; 16:1693-1702.

33. Both SK, van der Muijsenberg AJC, van Blitterswijk CA, de Boer J, de Bruijn JD. A Rapid and Efficient Method for Expansion of Human Mesenchymal Stem Cells. Tissue Eng 2007;13:3-9.

34. Carpenter $A E$, Jones $T R$, Lamprecht MR, Clarke C, Han Kan I, †, Friman O, Guertin DA, Han Chang J, Lindquist RA, Moffat J
Golland P, Sabatini DM. CellProfiler: image analysis software for identifying and quantifying cell phenotypes. Genome Biol 2006;7: R100-111.

35. Erbil Abaci H, Shen Y, Tan S, Gerecht S. Recapitulating physiological and pathological shear stress and oxygen to model vasculature in health and disease. Sci Rep 2014;4:4951 DOI: 10.1038/ srep04951.

36. Habibovic $P, \mathrm{Li} J$, van der Valk CM, Meijer $G$, Layrolled $P$, van Blitterswijk CA, de Groot K. Biological Performance of Uncoated and Octacalcium Phosphate-Coated Ti6Al4V. Biomaterials 2005; 26:23-36.

37. Barrère $F$, Layrolle $P$, van Blitterswijk CA, de Groot K. Biomimetic Calcium phosphate Coatings on Ti6AI4V: A Crystal Growth Study of Octacalcium Phosphate and Inhibition by $\mathrm{Mg}^{2+}$ and $\mathrm{HCO}_{3}$. Bone 1999;25:107S-111S.

38. Barrère $F$, Layrolle $P$, van Blitterswijk CA, de Groot K. Biomimetic Coatings on Titanium: A Crystal Growth Study of Octacalcium Phosphate. J Mater Sci: Mater Med 2001;12:529-534.

39. Pasqualetti S, Banfi G, Mariotti M. The Effects of Strontium on Skeletal Development in Zebrafish Embryo. J Trace Elem Med Biol 2013:27:375-379.

40. Blake GM, Fogelman I. Strontium Ranelate Does not Have an Anabolic Effect on Bone. Bone 2013;9:696-670.

41. Chavassieux P, Meunier PJ, Roux JP, Portero-Muzy N, Pierre M, Chapurlat R. Bone Histomorphometry of Transiliac Paired Bone Biopsies After 6 or 12 Months of Treatment with Oral Strontium Ranelate in 387 Osteoporotic Women: Randomized Comparison to Alendronate. J Bone Miner Res 2014;29:618-628.

42. Guo D, Xu K, Zhao X, Han Y. Development of a StrontiumContaining Hydroxyapatite Bone Cement. Biomaterials 2005;26: 4073-4083.

43. Barrère $F$, van der Valk $C M$, Dalmeijer RAJ, van Blitterswijk $C A$, de Groot K, Layrolle P. In Vitro and In Vivo Degradation of Biomimetic Octacalcium Phosphate and Carbonate Apatite Coatings on Titanium Implants. J Biomed Mater Res Part A 2002;64A:378-387.

44. Pors Nielsen S. The Biological Role of Strontium. Bone 2004;35: 583-588.

45. Treiser MD, Yang EH, Gordonov S, Cohen DM, Androulakis IP, Kohn J, Chen CS, Moghe PV. Cytoskeleton-Based Forecasting of Stem Cell Lineage Fates. Proc Natl Acad Sci USA 2010;107:610-615.

46. Barradas AMC, Fernandes HAM, Groen N, Chai Y, Schrooten J, van de Peppel J, van Leeuwen JPTM, van Blitterswijk CA, de Boer J. A Calcium-Induced Signaling Cascade Leading to Osteogenic Differentiation of Human Bone Marrow-Derived Mesenchymal Stromal Cells. Biomaterials 2012;33:3205-3215.

47. McBeath R, Pirone DM, Nelson CM, Bhadriraju K, Chen CS. Cell Shape, Cytoskeletal Tension, and RhoA Regulate Stem Cell Lineage Commitment. Dev Cell 2004;6:483-495.

48. Dalby MJ, Gadegaard N, Tare R, Andar A, Riehle MO, Herzyk P, Wilkinson CDW, Oreffo ROC. The Control of Human Mesenchymal Cell Differentiation Using Nanoscale Symmetry and Disorder. Nat. Mater 2007;6:997-1003.

49. Brennan TC, Rybchyn MS, Green W, Atwa S, Conigrave AD, Mason RS. Osteoblasts Play Key Roles in the Mechanisms of Action of Strontium Ranelate. Br J Pharmacol 2009;157:12911300.

50. Barbara A, Delannoy P, Denis BG, Marie PJ. Normal Matrix Mineralization Induced by Strontium Ranelate in MC3T3-E1 Osteogenic Cells. Metabolism 2004;53:532-537.

51. Saidak Z, Marie PJ. Strontium Signaling: Molecular Mechanisms and Therapeutic Implications in Osteoporosis. Pharmacol Ther 2012;136:216-226.

52. Choudhary S, Halbout P, Alander C, Raisz L, Pilbeam C. Strontium Ranelate Promotes Osteoblastic Differentiation and Mineralization of Murine Bone Marrow Stromal Cells: Involvement of Prostaglandins. J Bone Miner Res 2007;22:1002-1010.

53. Walsh S, Jordan GR, Jefferiss C, Stewart K, Bresford JN. High Concentrations of Dexamethasone Suppress the Proliferation but not the Differentiation or Further Maturation of Human Osteoblast Precursors In Vitro: Relevance to Glucocorticoid-Induced Osteoporosis. Rheumatology 2001:40:74-83.

54. Beresford JN, Joyner CJ, Devlin C, Triffitt JT. The Effects of Dexamethasone and 1,25-Dihydroxyvitamin D on Osteogenic 
Differentiation of Human Marrow Stromal Cells In Vitro. Archs Onrl Bid 1994;39:941-947.

55. Langenbach F, Handschel J. Effects of Dexamethasone, Ascorbic Acid and $\beta$-Glycerophosphate on the Osteogenic Differentiation of Stem Cells In Vitro. Stem Cell Res Ther 2013;4:117-123.

56. Weiler HA, Wang Z, Atkinson SA. Dexamethasone Treatment Impairs Calcium Regulation and Reduces Bone Mineralization in Infant. Am J Clin Nutr 1995;61:805-811.

57. Wiontzek M, Matziolis G, Schuchmann S, Gaber T, Krocker D, Duda G, Burmester GR, Perka C, Buttgereit F. Effects of Dexamethasone and Celecoxib on Calciumhomeostasis and Expression of Cyclooxygenase-2 mRNA in MG-63 Human Osteosarcoma Cells. Clin Exp Rheumatol 2006;24:366-372.

58. Danoux CBSS, Bassett DC, Othman Z, Rodrigues Al, Reis RL, Barralet JE, van Blitterswijk CIA, Habibovic P. Elucidating the individual effects of calcium and phosphate ions on hMSCs by using composite materials. Acta Biomater 2015;17:1-15.
59. Barradas AMC, Yuan $\mathrm{H}$, van Blitterswijk CA, Habibovic P. Osteoinductive biomaterials: current knowledge of properties, experimental models and biological mechanisms. Eur Cell Mater 2011;21: 407-429.

60. Habibovic $P$, Yuan $H$, van der Valk CM, Meijer $G$, van Blitterswijk CA, de Groot K. 3D microenvironment as essential element for osteoinduction by biomaterials. Biomaterials 2005;26: 3565-3575.

61. Zhang J, Luo $X$, Barbieri D, Barradas AMC, de Bruijn JD, van Blitterswijk CA, Yuan $\mathrm{H}$. The size of surface microstructures as an osteogenic factor in calcium phosphate ceramics. Acta Biomater 2014;10:3254-3263.

62. Unadkat HV, Hulsman $M$, Cornelissen $K$, Papenburg BJ, Truckenmüller RK, Carpenter AE, Wessling M, Post GF, Uetz M, Reinders MJT, Stamatialis D, van Blitterswijk CA, de Boer J. An Algorithm-Based Topographical Biomaterials Library to Instruct Cell Fate. Proc Natl Acad Sci USA 2011;108:16565-1657. 